\title{
Jerk within the Context of Science and Engineering-A Systematic Review
}

\author{
Hasti Hayati ${ }^{1, *(\mathbb{D}}$, David Eager ${ }^{1} \mathbb{D}$, Ann-Marie Pendrill ${ }^{2} \mathbb{D}$ and Hans Alberg ${ }^{3}$ \\ 1 School of Mechanical and Mechatronic Engineering, University of Technology Sydney, P.O. Box 123, \\ Broadway, Ultimo, NSW 2007, Australia; David.Eager@uts.edu.au \\ 2 National Resource Centre for Physics Education, Lund University, Box 118, SE 22100 Lund, Sweden; \\ Ann-Marie.Pendrill@fysik.lu.se \\ 3 Hägerstens Alle 20, lgh 1303, SE 12937 Hägersten, Sweden; alberg.hans@gmail.com \\ * Correspondence: Hasti.Hayati@uts.edu.au
}

Received: 14 September 2020; Accepted: 10 October 2020; Published: 21 October 2020

\begin{abstract}
Rapid changes in forces and the resulting changes in acceleration, jerk and higher order derivatives can have undesired consequences beyond the effect of the forces themselves. Jerk can cause injuries in humans and racing animals and induce fatigue cracks in metals and other materials, which may ultimately lead to structure failures. This is a reason that it is used within standards for limits states. Examples of standards which use jerk include amusement rides and lifts. Despite its use in standards and many science and engineering applications, jerk is rarely discussed in university science and engineering textbooks and it remains a relatively unfamiliar concept even in engineering. This paper presents a literature review of the jerk and higher derivatives of displacement, from terminology and historical background to standards, measurements and current applications.
\end{abstract}

Keywords: jerk; acceleration onset; higher-order derivatives of acceleration; jounce; acceleration-dot

\section{Introduction}

Jerk-the time derivative of acceleration-is an important consideration for many applications in science and engineering. For example, jerk has long been used as a design factor to ensure ride comfort, e.g., in amusement rides [1-7], ships [8-10], lifts/elevators [11] and buses [12], and there are many reasons to believe that the relevance of jerk-and higher derivatives of displacement-will increase. A number of ISO standards also refer to jerk [13-19].

Displacement, velocity and acceleration are well known concepts for everyone who has studied physics at secondary level, whereas jerk - the time derivative of acceleration-and higher derivatives are rarely mentioned, let alone discussed, even in university physics or engineering textbooks. This omission was pointed out three decades ago by Sandin [20], who only found one reference to jerk [21] in a dozen reviewed text books. In addition, in an earlier article for university physics teachers [22], Schot presented the concept and also discussed the radial and tangential components of jerk. However, despite this early effort for jerk to be included in text books, jerk is not yet discussed in physics and engineering courses, except for a few textbooks [23-25]. The lack of detail in textbooks also contributes to some confusion concerning terminology.

Higher derivatives have been discussed by Thompson in a conference presentation [26], where he argued that since immediate acceleration onsets have a detrimental effect on equipment, acceleration should be ramped up by placing a limit on jerk. He then proposed an alternative strategy, claimed to be even better, which is ramping up jerk by placing a limit on its higher derivatives of snap, crackle and pop. However, the details of his studies are beyond the scope of this work. 
Jerk and higher derivatives of acceleration are relevant for understanding the impact of motion and vibrations in a wide range of applications, as reviewed in this paper [1-12,27-195]

The considerable interest is also reflected in the large number of downloads $(>100,000)$ of a 2016 paper on jerk and higher derivatives [1].

To support secondary school teachers and university lecturers who would like to introduce the concept of jerk, as well as higher derivatives, in their science or engineering courses, we have conducted a thorough systematic review, from terminology and historical background to standards, measurements and current applications. The articles are divided, based on the applications of jerk, into twenty-one categories. Each article is ranked against where it is published using Scientific Journal Rankings (SJR)-Scimago index, from the quartiles Q1 to Q4, where Q1 is occupied by the top 25\% of journals, Q2 by the top 25\% to $50 \%$ and so on. We used N/A for thesis, reports, and conferences and journals where we were unable find any information with regards to their quality. Other sources are also included in the reference list. The rationale for including these sources is the scarcity of research on jerk. It is then the responsibility of the reader to evaluate the articles against their own objective. A number of papers have been included which use the concept of jerk, even if they don't explicitly mention the term or only refer to it briefly.

\section{Background}

There is a limited number of good textbooks about the history of mechanics. The best are probably Szabo [196] (in German) and Dugas [197] (in French and translated into English [198]). Although these books contain a lot of interesting information, neither covers jerk or higher derivatives.

Newton's second law of motion is commonly written as $\mathbf{F}=m \mathbf{a}$, i.e., "force equals mass times acceleration", although Newton did not use the term acceleration in his equations but stated that the rate of change in momentum is equal to the applied force. The concept of acceleration was formalized by Pierre Varignon (1654-1722) [199]. Before the second world war German engineers, including Melchior [200] and Schlobach [201], pointed at applications of jerk for handheld machines.

One aspect that is frequently overlooked is terminology. By standardizing terminology, misunderstandings could be avoided, communication between scientists from different disciplines could be enabled, and searches on the global network would be facilitated. The term "jerk" for the first derivative of acceleration seems to be most widely used. However, alternative terms like "acceleration onset rate" are also used, e.g., Whinnery et al. [202], ISO 2041 [13] and a report by NASA [94].

The higher derivatives are less familiar, and different terminologies have been used by different groups. The term "jounce" is sometimes used to describe the fourth derivative of position, and in some Japanese articles it is referred to as "jerk-dot" [148,173,175].

In this work, we will use the more common terms "snap", "crackle" and "pop" for the 4th-6th derivatives (named after pictorial characters on Kellogs' Corn Flakes packages from the thirties). For the 7th-10th derivatives, the terms "lock", "drop", "shock" and "put" have been proposed informally, although we have been unable to find them in the literature.

\section{Method}

Articles in the period from 2015 to 2020 with the term "jerk" mentioned in the title were looked up in an electronic database (Scholar.google.com), excluding citations and patents. There were 550 results. The initial 550 articles was refined by excluding 129 based on title, non-English language and duplication. Of the remaining 421 articles, 147 articles were excluded in a more detailed subsequent assessment that included a review of the abstracts and conclusions, and their source, i.e., low-quality journals/conferences. Of the remaining 274 remaining articles, 139 articles that referred to jerk in the context of chaotic systems and nonlinear dynamics were excluded. Terms signaling this context include jerk system, hyper-jerk system, chaotic jerk-system, jerk attractors, jerk circuit, jerk dynamics, jerk map, jerk function, jerk oscillators and jerk equations, and traffic jerk model $(n=17)$ articles that 
used jerk in the context of weightlifting were removed, since this refers to a weightlifting technique rather than the jerk itself.

In addition to the articles emerging from this database search, the authors were aware of 84 articles before 2015, as well as articles where jerk was not mentioned in the title. These articles have been included in the review. The inclusion-exclusion criteria flow chart is given in Figure 1.

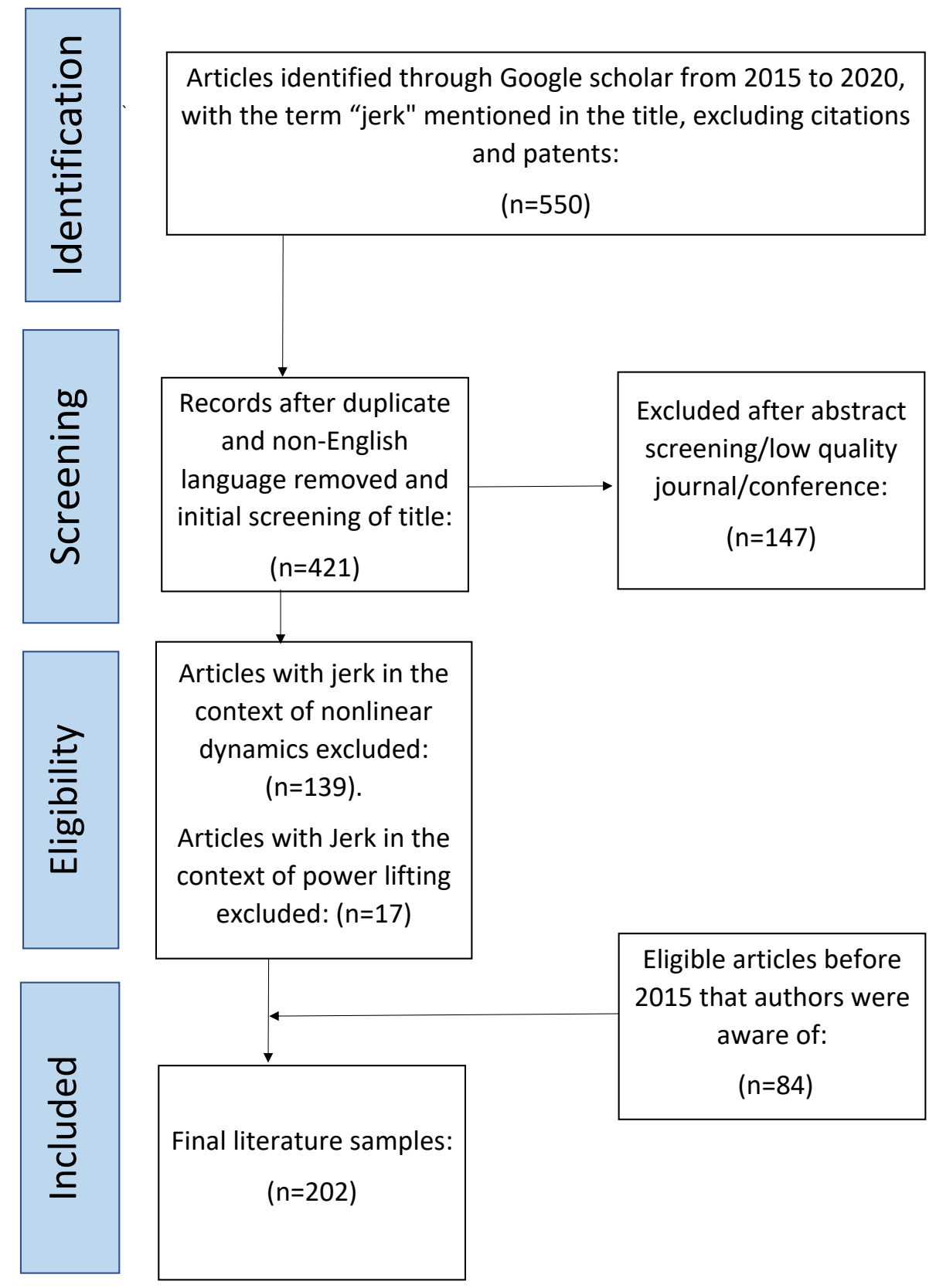

Figure 1. Systematic review 'inclusion-exclusion criteria' flow chart.

After reviewing the collected literature $(\mathrm{n}=202)$ and those articles that the author were aware of, the applications of jerk were categorised into 20 categories.

\section{Categorisation of Jerk Applications}

The 21 jerk categories chosen with their respective references were:

1. Jerk in advanced manufacturing [27-90]; 
2. Jerk in amusement rides $[1-7,14]$;

3. Jerk in cosmology and space technology [91-94];

4. Jerk in criteria for discomfort $[1,4,5,9,10,12,19,25,95-131]$;

5. Jerk in equation of motion [132-136];

6. Jerk in global positioning systems (GPS) $[137,138]$;

7. Jerk in human tolerance $[202,203]$;

8. Jerk in kinesiology [139-147];

9. Jerk in measurement [148-151];

10. Jerk in motion analysis $[152,153]$;

11. Jerk in ornithology [154];

12. Jerk in racing [155-160];

13. Jerk in sea-keeping $[8-10,122,126,204]$;

14. Jerk in seismic analysis $[134,161-170]$;

15. Jerk in shock response spectrum $[8,205]$;

16. Jerk in sport science $[1,171,172]$;

17. Jerk in standards [13-19]

18. Jerk in structural health monitoring [173-176];

19. Jerk in technical pain [177];

20. Jerk in unmanned aerial vehicle (UAV) [11,178-186]; and

21. Jerk in vehicles (ride comfort $[12,15,17,19,25,45,95,98-106,108,109,111-113,115,118-121$, 123-125,127-131], anti-jerk controller design [95,98-102,109,111,119,120,130], autonomous vehicles $[12,16,114,123,187,188]$, and other $[111,187,189-195]$.

The next section presents brief summaries of the papers in the different categories.

\section{Results and Discussion}

\subsection{Jerk in Advanced Manufacturing}

Jerk in advanced manufacturing can be categorised into jerk in industrial robots [27-63], machining [64-78], motors [79-83], and 3D printers [84-90].

\subsubsection{Jerk in Industrial Robots}

Jerk is mainly used to generate smooth trajectories in industrial robots (also referred to as manipulators) [27-63]. It is outside the scope and purpose of this paper to explain the jerk-controller. Details (author, source, SJR ranking and the title) of the Q1 articles are tabulated in Table 1.

As mentioned above, all of the cited reference used jerk as a limit for generating or controlling a smooth motion.

\subsubsection{Jerk in 3D Printers}

In recent years, jerk has been used in 3D printers [84-90]. One important consideration in 3D printing is that the term jerk, in the majority of 3D firmware, is defined in terms of the maximum "instantaneous" velocity change without consideration of the time required [84,90].

Inconsistent terminology causes confusion and needs to be addressed in the future. Notwithstanding, in an article on 3D printing by Hernandez [86], the actual jerk was considered (see Table 2).

\subsubsection{Jerk in Machining}

Jerk is recently used in generating smooth trajectories in machining [64-78]. Details of Q1 articles are tabulated in Table 3. 
Table 1. Jerk in industrial robots.

\begin{tabular}{|c|c|c|c|}
\hline Author & Source & SJR & Title \\
\hline Lang (2015) [42] & $\begin{array}{l}\text { IEEE Robotics } \\
\text { Automation Letters }\end{array}$ & Q1 & $\begin{array}{l}\text { Path-accurate online trajectory generation for jerk-limited industrial robots } \\
\text { real-time trajectory generation for industrial robot which complies with standards } \\
\text { of smooth motion in robotic arms. }\end{array}$ \\
\hline Chen (2015) [85] & $\begin{array}{l}\text { IET Control Theory } \\
\text { Applications }\end{array}$ & Q1 & $\begin{array}{l}\text { Minimum jerk norm scheme applied to obstacle avoidance of redundant robot } \\
\text { arm with jerk bounded and feedback control. }\end{array}$ \\
\hline Chen (2015) [29] & Automatica & Q1 & $\begin{array}{l}\text { Composite jerk feed-forward and disturbance observer for robust tracking of } \\
\text { flexible systems. }\end{array}$ \\
\hline $\begin{array}{l}\text { Bianco } \\
(2017)[28]\end{array}$ & $\begin{array}{l}\text { Robotics } \\
\text { Computer-Integrated } \\
\text { Manufacturing }\end{array}$ & Q1 & $\begin{array}{l}\text { A scaling algorithm for the generation of jerk-limited trajectories in the operational } \\
\text { space. }\end{array}$ \\
\hline $\begin{array}{l}\text { Besset } \\
(2017)[27]\end{array}$ & $\begin{array}{l}\text { Control Engineering } \\
\text { Practice }\end{array}$ & Q1 & $\begin{array}{l}\text { Constraints and limits on velocity, acceleration, and jerk FIR filter-based online } \\
\text { jerk-constrained trajectory generation. }\end{array}$ \\
\hline $\begin{array}{l}\text { Kaserer } \\
(2018)[41]\end{array}$ & $\begin{array}{l}\text { IEEE Robotics } \\
\text { Automation Letters }\end{array}$ & Q1 & $\begin{array}{l}\text { Nearly optimal path following with jerk and torque rate limits using dynamic } \\
\text { programming. }\end{array}$ \\
\hline $\begin{array}{l}\text { Kaserer } \\
(2018)[40]\end{array}$ & $\begin{array}{l}\text { IEEE Transactions on } \\
\text { Robotics }\end{array}$ & Q1 & $\begin{array}{l}\text { Online robot-object synchronization with geometric constraints and limits on } \\
\text { velocity, acceleration, and jerk. }\end{array}$ \\
\hline $\begin{array}{l}\text { Huang } \\
(2018)[38]\end{array}$ & $\begin{array}{l}\text { Mechanism Machine } \\
\text { Theory }\end{array}$ & Q1 & Optimal time-jerk trajectory planning for industrial robots. \\
\hline Rojas (2019) [52] & $\begin{array}{l}\text { IEEE Robotics } \\
\text { Automation Letters }\end{array}$ & Q1 & $\begin{array}{l}\text { A variational approach to minimum-jerk trajectories for psychological safety in } \\
\text { collaborative assembly stations. }\end{array}$ \\
\hline $\begin{array}{l}\text { Palleschi } \\
\text { (2019) [49] }\end{array}$ & $\begin{array}{l}\text { IEEE Robotics } \\
\text { Automation Letters }\end{array}$ & Q1 & Time-optimal path tracking for jerk controlled robots. \\
\hline Dai (2020) [33] & $\begin{array}{l}\text { IEEE Transactions on } \\
\text { Automation Science and } \\
\text { Engineering }\end{array}$ & Q1 & $\begin{array}{l}\text { Planning jerk-optimized trajectory with discrete time constraints for redundant } \\
\text { robots. }\end{array}$ \\
\hline
\end{tabular}


Table 2. Jerk in 3D printers.

\begin{tabular}{lllll}
\hline Author & Source & SJR & Purpose and Finding & Comments \\
\hline $\begin{array}{l}\text { Hernandez } \\
\text { (2015) [86] }\end{array}$ & $\begin{array}{l}\text { International Journal of } \\
\text { Aviation, Aeronautics, } \\
\text { Aerospace }\end{array}$ & Q4 & $\begin{array}{l}\text { To analyse factors which affect the dimensional precision of consumer 3D printing. } \\
\text { The jerk was believed to play an insignificant role in printing quality but it was } \\
\text { observed that a single instant of apparent error due to jerk could be accounted for, } \\
\text { and should be considered by changing the the way infill was applied. }\end{array}$ & $\begin{array}{l}\text { The man jerk is an input parameter } \\
\text { that can be by the user to control the } \\
\text { have a cleaner print as a result. }\end{array}$ \\
\hline
\end{tabular}

Table 3. Jerk in machining.

\begin{tabular}{|c|c|c|c|c|}
\hline Author & Source & SJR & Purpose and Findings & Comments \\
\hline $\begin{array}{l}\text { Zhang } \\
(2019)[78]\end{array}$ & $\begin{array}{l}\text { Computer-Aided } \\
\text { Design }\end{array}$ & Q1 & $\begin{array}{l}\text { Generating a smooth curve, mainly at junctions, in computer numerical control } \\
\text { (CNC) machining is a challenge. In this work, a new algorithm, which is claimed } \\
\text { to have a jerk-smooth trajectory controller, is proposed. }\end{array}$ & $\begin{array}{l}\text { Jerk as a measure to generate smooth and } \\
\text { accurate trajectories. }\end{array}$ \\
\hline $\begin{array}{l}\text { Schroedter } \\
(2018)[74]\end{array}$ & Mechatronics & Q1 & $\begin{array}{l}\text { A flatness-based feed forward control method using jerk-limited trajectories, which } \\
\text { is based on a mechatronic micro mirror model, is proposed to reduce undesired } \\
\text { oscillations in micro-scanners. }\end{array}$ & $\begin{array}{l}\text { Jerk as a measure to generate smooth and } \\
\text { accurate trajectories. }\end{array}$ \\
\hline $\begin{array}{l}\text { Dumanli } \\
\text { (2018) [68] }\end{array}$ & Precision Engineering & Q1 & $\begin{array}{l}\text { Obtaining a smooth surface manufactured in a timely manner is a challenge in } \\
\text { different industries, and, therefore, different smooth-trajectory controllers have } \\
\text { been developed. In this study, a novel jerk value decision-making process is } \\
\text { proposed for the parts-machining process. }\end{array}$ & $\begin{array}{l}\text { Jerk as a measure to generate smooth and } \\
\text { accurate trajectories. }\end{array}$ \\
\hline $\begin{array}{l}\text { Alzaydi } \\
\text { (2019) [65] }\end{array}$ & $\begin{array}{l}\text { Mechanical Systems } \\
\text { Signal Processing }\end{array}$ & Q1 & $\begin{array}{l}\text { Current machine tool controllers cannot fully benefit from the speed of the drilling } \\
\text { laser as they are not equipped with a proper trajectory function. In this work, a } \\
\text { time-optimal and minimum jerk trajectory generator is designed and implemented } \\
\text { on a gas turbine combustion chamber. The results showed } 6 \% \text { time-reduction as } \\
\text { well as reduced oscillation due to controlled jerk. }\end{array}$ & $\begin{array}{l}\text { Jerk as a measure to generate smooth and } \\
\text { accurate trajectories. }\end{array}$ \\
\hline $\begin{array}{l}\text { Hashemian } \\
(2020)[69]\end{array}$ & $\begin{array}{l}\text { Computer-Aided } \\
\text { Design }\end{array}$ & Q1 & $\begin{array}{l}\text { A novel jerk-minimised trajectory controller for multi-axis flank CNC machining } \\
\text { is developed in this work. }\end{array}$ & $\begin{array}{l}\text { Jerk as a measure to generate smooth and } \\
\text { accurate trajectories. }\end{array}$ \\
\hline $\begin{array}{l}\text { Zhang et al. } \\
\text { (2018) [64] }\end{array}$ & $\begin{array}{l}\text { The International } \\
\text { Journal of Advanced } \\
\text { Manufacturing } \\
\text { Technology }\end{array}$ & $\mathrm{N} / \mathrm{A}$ & $\begin{array}{l}\text { Corner smooth machining in high speed machining causes issues in advanced } \\
\text { manufacturing. Current solution is based on the jerk-limited acceleration profile } \\
\text { from the perspective of kinematics that generate continuous acceleration transition } \\
\text { profiles. They offer the same approach but for a higher derivative of jerk (jounce). }\end{array}$ & $\begin{array}{l}\text { They used Jerk onset (jounce) for } \\
\text { smoothing algorithm for the corner } \\
\text { motion in high speed machining. }\end{array}$ \\
\hline
\end{tabular}




\subsubsection{Jerk in Motors}

Jerk is also used in motors mostly a as a measure to control/generate smooth trajectories [79-83] (Table 4).

\subsection{Jerk in Amusement Rides}

Jerk is rarely mentioned in textbooks but is quite an important physical parameter, as we quite often experience it in daily life. One important aspect of jerk is that jerk is an element in the comfort and safety of amusement rides, as well as reducing the need for equipment maintenance (Table 5).

\subsection{Jerk in Cosmology and Space Technology}

Jerk is used in cosmology as well as space technology. Details of articles which were eligible based on the inclusion criteria of the current work are given in Table 6.

\subsection{Jerk in Criteria for Discomfort}

Ride comfort is an important parameter in amusement rides [1,4,5], sea-keeping $[9,10,122,126]$ and traditional land-based vehicles [12,25,45,95,98-106,108,109,111-113,115,118-121,123-125,127-131]. There are still discussions ongoing regarding the significance of jerk regarding ride comfort for vehicles, and jerk is probably a better measure for driving comfort than acceleration, as pointed out by van Santen [128] and confirmed, e.g., in the study by Grant and Haycock [107]. Jerk monitoring also offers insurance companies a way to follow up the behaviour of drivers, as a basis for car insurance pricing [195].

The Dutch institutes TNO and MARIN have initiated a joint project to study the impact of jerk on the comfort of passengers in a master thesis conducted by Werkman [10]. Details of this work are given in Section 3.4.2 of this paper.

Förstberg [104] investigated ride comfort and motion sickness in trains. The results indicated that "it is motion dose from horizontal jerk or horizontal acceleration as well as roll acceleration or roll velocity that is the primary causes of provocation." Unfortunately, Förstberg passed away shortly after presenting his thesis.

Svensson and Ericsson [123] referred to concrete jerk values from American Association of State Highway and Transportation Official Standards (AASHTO; 2001) [206] in their master thesis. A value of lateral jerk ranging from 0.03 to $0.09 \mathrm{~g} / \mathrm{s}$ has been used for highway design. Jia [25] claims that the jerk should be below $0.2 \mathrm{~g} / \mathrm{s}$ in trains for passenger comfort. Martin and Litwhiler [118] investigated acceleration and jerk profiles in the metro-rail system in Washington DC and found jerk peaks of around $1.3 \mathrm{~g} / \mathrm{s}$.

Minimising the discomfort experienced during a journey between two points with the fixed travel time was studied by Anderson et al. [96]. They proposed jerk as a discomfort criteria. Their work was then revisited by Antonelli and Klotz [97] and Lemos [116] one and three years later, respectively. The jerk is proposed as a discomfort criteria. Antonelli and Klotz (2017) [97] and Lemos (2019) [116], commented on this work and mentioned that the integral of the square of acceleration and the integral of square of jerk should be considered as criteria for discomfort.

\subsubsection{Jerk in Ride Comfort: Amusement Rides}

Jerk is used as a ride comfort measure in amusement rides [1,4,5]. Details of studies mentioning jerk as a ride comfort parameter in amusement rides are given in Section 3.2, Table 5.

\subsubsection{Jerk in Ride Comfort: Sea-Keeping}

Jerk is used a ride comfort measure in sea-keeping $[9,10,122,126]$. Details of these studies are given in below Table 7 . 
Table 4. Jerk in motors.

\begin{tabular}{|c|c|c|c|c|}
\hline Author & Source & SJR & Purpose and Findings & Comments \\
\hline $\begin{array}{l}\text { Masoudi } \\
(2016)[82]\end{array}$ & $\begin{array}{l}\text { IET Electric Power } \\
\text { Applications }\end{array}$ & Q1 & $\begin{array}{l}\text { Although the linear switched reluctance motors (LSRMs) have } \\
\text { many benefits such as being low cost, and having a comparatively } \\
\text { high force-to-mass ratio and no need for mechanical rotary } \\
\text { to linear motion, as converters, they have limited application } \\
\text { because of their force ripple. To control this force ripple, a new } \\
\text { control model based on a minimum jerk model is proposed, which } \\
\text { can be used in elevator applications. }\end{array}$ & $\begin{array}{l}\text { A controller based on a } \\
\text { minimum jerk model for } \\
\text { LSRM motors. }\end{array}$ \\
\hline $\begin{array}{l}\text { Jinhui } \\
\text { (2017) [80] }\end{array}$ & Mechatronics & Q1 & $\begin{array}{l}\text { A minimum jerk trajectory controller to enhance the smoothness } \\
\text { and stability of a rotor motor is developed in this work. }\end{array}$ & $\begin{array}{l}\text { Jerk as a measure to generate } \\
\text { smooth trajectories. }\end{array}$ \\
\hline
\end{tabular}

Table 5. Jerk in amusement rides.

\begin{tabular}{|c|c|c|c|c|}
\hline Author & Source & SJR & Purpose and Findings & Comments \\
\hline $\begin{array}{l}\text { Pendrill } \\
\text { (2005) [2] }\end{array}$ & Physics Education & Q3 & $\begin{array}{l}\text { Although textbook loops are often circular, real roller coaster loops are not. } \\
\text { This paper looks into the mathematical description of various possible } \\
\text { loop shapes, as well as their riding properties. }\end{array}$ & $\begin{array}{l}\text { Jerk is mentioned indirectly, in the } \\
\text { context of using clothoid curves for } \\
\text { roller coaster loops. }\end{array}$ \\
\hline $\begin{array}{l}\text { Eager et al. } \\
\text { (2016) [1] }\end{array}$ & $\begin{array}{l}\text { European Journal of } \\
\text { Physics }\end{array}$ & Q2 & $\begin{array}{l}\text { The concept of jerk is discussed using trampoline and amusement rides } \\
\text { (roller coasters). The effect of jerk on human body is also discussed. } \\
\text { The importance of jerk in amusement rides (roller coasters): safety } \\
\text { (avoiding whiplash); ride comfort; when the safety of the passenger } \\
\text { is not an issue, reducing the maintenance cost due to snap. }\end{array}$ & $\begin{array}{l}\text { Jerk is important and is experienced } \\
\text { in daily life, yet is not well-explained } \\
\text { and understood. }\end{array}$ \\
\hline $\begin{array}{l}\text { Sicat et al. } \\
(2018)[4]\end{array}$ & $\begin{array}{l}\text { Proceedings for the } \\
\text { Annual Occupational } \\
\text { Ergonomics and } \\
\text { Safety Conference }\end{array}$ & $\mathrm{N} / \mathrm{A}$ & $\begin{array}{l}\text { The design and validation protocol for wearable sensor technology used } \\
\text { to collect acceleration and g-force exposure of a zip line rider is studied } \\
\text { in this work. }\end{array}$ & $\begin{array}{l}\text { They have briefly mentioned the } \\
\text { importance of jerk (referred to it as } \\
\text { rate of change of acceleration) in } \\
\text { the ride comfort and safety of the } \\
\text { passengers. Refers to Eager et al. [1]. }\end{array}$ \\
\hline
\end{tabular}


Table 5. Cont.

\begin{tabular}{|c|c|c|c|c|}
\hline Author & Source & SJR & Purpose and Findings & Comments \\
\hline $\begin{array}{l}\text { Väisänen } \\
\text { (2018) [5] }\end{array}$ & Master thesis & $\mathrm{N} / \mathrm{A}$ & $\begin{array}{l}\text { A literature review to present general guidelines and principles of what } \\
\text { is included in the design and engineering of roller coasters and other } \\
\text { guest functions attached to them. }\end{array}$ & $\begin{array}{l}\text { They have briefly mentioned jerk } \\
\text { as a limit which may become } \\
\text { standardized in future, since } \\
\text { it affects the ride comfort and } \\
\text { experience. }\end{array}$ \\
\hline $\begin{array}{l}\text { Pendrill et al. } \\
\text { (2019) [6] }\end{array}$ & Physics Education & Q3 & $\begin{array}{l}\text { Assessed the first-year university understanding of the vertical motion on } \\
\text { a roller coaster loop. It was found that students have partial conceptions } \\
\text { about force and motion and contradictions in their responses and do not } \\
\text { have a good understanding of abrupt changes in jerk. }\end{array}$ & $\begin{array}{l}\text { The importance of including jerk in } \\
\text { physics textbooks. }\end{array}$ \\
\hline $\begin{array}{l}\text { Pendrill et al. } \\
\text { (2020) [7] }\end{array}$ & Physics Education & Q3 & $\begin{array}{l}\text { The effect of acceleration, jerk, snap and vibration on the ride comfort } \\
\text { experience and safety of roller coaster rides is analysed in this work, via } \\
\text { authentic data from a dive coaster as an example. }\end{array}$ & $\begin{array}{l}\text { Jerk and snap are considered as ride } \\
\text { comfort criteria in amusement rides. }\end{array}$ \\
\hline
\end{tabular}

Table 6. Jerk in Cosmology and space technology.

\begin{tabular}{|c|c|c|c|c|}
\hline Author & Source & SJR & Purpose and Finding & Comments \\
\hline Visser (2004) [91] & $\begin{array}{l}\text { Classical } \\
\text { Gravity }\end{array}$ & $\mathrm{N} / \mathrm{A}$ & $\begin{array}{l}\text { To obtain a higher accuracy of jerk and snap parameters in cosmological Equations } \\
\text { of States (EOS). It is found that although other parameters are known to high } \\
\text { accuracy, the jerk and snap are still poorly estimated. This fact would cause direct } \\
\text { observational constraints on cosmological EOS if not properly addressed. }\end{array}$ & $\begin{array}{l}\text { The importance of the jerk and snap } \\
\text { in cosmological EOS and how the lack } \\
\text { of proper information has limited the } \\
\text { researchers of the field. }\end{array}$ \\
\hline $\begin{array}{l}\text { Hur-Diaz et al. } \\
\text { (2008) [92] }\end{array}$ & NASA technical report & $\mathrm{N} / \mathrm{A}$ & $\begin{array}{l}\text { In an article entitled "Three axis control of the Hubble Space Telescope using two } \\
\text { reaction wheels and magnetic torquer bars for science observations", jerk has been } \\
\text { used as a measure in maneuver planning. }\end{array}$ & $\begin{array}{l}\text { They considered maximum jerk as they } \\
\text { investigated possibilities for three-axis } \\
\text { control if two of the four reaction wheels } \\
\text { should fail. }\end{array}$ \\
\hline $\begin{array}{l}\text { STD, NASA } \\
\text { (2011) [94] }\end{array}$ & NASA technical report & $\mathrm{N} / \mathrm{A}$ & $\begin{array}{l}\text { Human-system standard. "The system shall limit crew exposure to acceleration } \\
\text { rates of change larger than } 500 \mathrm{~g} / \mathrm{s} \text { during any sustained }(>0.5 \mathrm{~s}) \text { acceleration } \\
\text { event." }\end{array}$ & $\begin{array}{l}\text { 'Acceleration onset' or 'acceleration rate } \\
\text { of change' is mentioned, but not jerk } \\
\text { explicitly. }\end{array}$ \\
\hline Ramon (2016) [93] & Master thesis & $\mathrm{N} / \mathrm{A}$ & $\begin{array}{l}\text { The touchdown dynamics of a lander was simulated. Jerk was a parameter } \\
\text { in designing a honeycomb damper, which aimed to dampen the impact forces } \\
\text { associated with touchdown dynamics of the lander. }\end{array}$ & $\begin{array}{l}\text { Considered jerk in the analysis of } \\
\text { touchdown dynamics of a lander in a } \\
\text { masters' project. }\end{array}$ \\
\hline
\end{tabular}


Table 7. Jerk as a criteria for discomfort: sea-keeping.

\begin{tabular}{|c|c|c|c|c|}
\hline Author & Source & SJR & Purpose and Findings & Comments \\
\hline $\begin{array}{l}\text { Tomi } \\
\text { (1961) [126] }\end{array}$ & $\begin{array}{l}\text { The Japan Society } \\
\text { of Naval Architects } \\
\text { and Ocean } \\
\text { Engineering }\end{array}$ & $\mathrm{N} / \mathrm{A}$ & $\begin{array}{l}\text { Ride comfort of passengers on ships were studied. The influence } \\
\text { of jerk on the rolling motion was discovered. }\end{array}$ & $\begin{array}{l}\text { One of the first references } \\
\text { considered jerk in ride comfort } \\
\text { in sea-keeping. Jerk is referred } \\
\text { to as the time derivative of } \\
\text { acceleration. }\end{array}$ \\
\hline $\begin{array}{l}\text { Shigehiro et al. } \\
\text { (2002) [122] }\end{array}$ & Fisheries science & Q3 & $\begin{array}{l}\text { The new evaluation method of passenger comfort is expressed by } \\
\text { vertical and lateral accelerations and exposure duration represents } \\
\text { the relationship between ship motions and seasickness. It is } \\
\text { confirmed that the correlation coefficient between the results of } \\
\text { the new method and the questionnaires given to the trainees show } \\
\text { fairly similar results. }\end{array}$ & $\begin{array}{l}\text { Jerk is not directly mentioned. } \\
\text { Only the work conducted } \\
\text { by Tomi [126] was briefly } \\
\text { mentioned. }\end{array}$ \\
\hline $\begin{array}{l}\text { Sosa \& Ooms } \\
(2016)[9]\end{array}$ & Report & $\mathrm{N} / \mathrm{A}$ & $\begin{array}{l}\text { The role of the roll stabiliser in the ride comfort in the yacht } \\
\text { industry is analysed. Jerk is mentioned as a ride comfort parameter } \\
\text { but was not included in the ride comfort rating used in this study. } \\
\text { Since it is seen in the literature that jerk is an important parameter } \\
\text { in this respect, further research in including jerk in the yacht ride } \\
\text { comfort rating is critical. }\end{array}$ & $\begin{array}{l}\text { Points to the need for more } \\
\text { studies of the effect of jerk in the } \\
\text { yacht industry. }\end{array}$ \\
\hline $\begin{array}{l}\text { Werkman } \\
(2019)[10]\end{array}$ & Master thesis & $\mathrm{N} / \mathrm{A}$ & To study the impact of jerk on comfort of passengers in sea-keeping. & $\begin{array}{l}\text { Points to the need for more } \\
\text { studies of the effect of } \\
\text { jerk. Importance of jerk in } \\
\text { sea-keeping and ride comfort in } \\
\text { general. }\end{array}$ \\
\hline
\end{tabular}




\subsubsection{Jerk in Ride Comfort: Vehicles}

Jerk has been used as a measure of ride comfort in vehicle engineering $[9,10,122,126]$ and vehicle land-based traditional [12,25,45,95,98-106,108,109,111-113,115,118-121,123-125,127-131]. Details of studies in Q1-Q4 journals are given in Table 8.

\subsection{Jerk in Equation of Motion (EOM)}

Jerk is proposed to be used in the EOM, and details of studies explored this can be found in Table 9. The idea has been discussed earlier but, to date, no concrete examples where someone claims that adding higher-order derivatives might explain the discrepancies between theory and observations, have been seen.

\subsection{Jerk in GPS Applications}

The following articles discussed use of jerk in Global Positioning Systems (GPS), mainly those types that should perform in harsh dynamic conditions such as satellite launch vehicles (Table 10).

\subsection{Jerk in Human Tolerance}

Details of works studying human tolerance to jerk are given in Table 11.

\subsection{Jerk In Kinesiology}

Jerk has been used in different kinesiologies in different fields of clinical studies in sport science. Below, those works which studied jerk in kinesiology for different applications [139-147] have been captured (Table 12).

Recently, jerk has gained interest in non-clinical trials. For instance, in a recent study by Zhang [145-147], jerk was used as a measure to detect fatigue in workers.

\subsection{Jerk in Measurement}

Jerk is normally measured indirectly by calculating the derivative of acceleration, which is measured by accelerometers. Below, those studies that developed a device to measure jerk are tabulated (Table 13).

\subsection{Jerk in Motion Analysis}

In motion analysis application, jerk is used as s measure in machine learning classifiers $[152,153]$ (Table 14).

\subsection{Jerk in Ornithology}

Ornithology is a branch of zoology which deals with birds. jerk has been used in one of the recent studies in this area, details of which are given in Table 15.

\subsection{Jerk in Greyhound Racing}

One of the interesting applications (refer to Table 16) of jerk is in high-speed sprint racing, such as greyhound racing. Recent articles on racing greyhounds, mainly the one in Nature's Scientific Report [160], clearly show its importance.

\subsection{Jerk in Sea-Keeping}

Jerk in sea-keeping is considered in both passengers' ride comfort and analysing shock spectrum in high-speed crafts [8-10,122,126,204] (Table 17). 
Table 8. Jerk as a criteria for discomfort: vehicles.

\begin{tabular}{|c|c|c|c|c|}
\hline Author & Source & SJR & Purpose and Findings & Comments \\
\hline $\begin{array}{l}\text { Deshmuck et al. } \\
\text { (2016) [103] }\end{array}$ & $\begin{array}{l}\text { International Journal } \\
\text { of } \quad \text { Passenger } \\
\text { Cars-Mechanical } \\
\text { Systems }\end{array}$ & Q3 & $\begin{array}{l}\text { The frequency characteristics of vehicle motion are studied to derive the } \\
\text { inherent jerk. A new method is proposed, which, unlike the conventional } \\
\text { method that uses the peak of jerk as a performance index, can differentiate } \\
\text { the perceivable frequencies from the test data and quantify the actual } \\
\text { jerk. }\end{array}$ & $\begin{array}{l}\text { A new method to obtain inherent } \\
\text { jerk was proposed. }\end{array}$ \\
\hline $\begin{array}{l}\text { Liu et } \\
(2016)[117]\end{array}$ & $\begin{array}{l}\text { Journal of } \\
\text { Dynamic Systems, } \\
\text { Measurement, } \\
\text { Control }\end{array}$ & Q1 & $\begin{array}{l}\text { A new low-jerk suspension control system by mixing skyhook } \\
\text { (SH), acceleration-driven-damper (ADD) is proposed in this work. } \\
\text { The characteristics of the SH-ADD suspension system are compared both } \\
\text { numerically and experimentally with other suspension control system. }\end{array}$ & $\begin{array}{l}\text { Jerk is as a measure in designing } \\
\text { suspension systems. }\end{array}$ \\
\hline $\begin{array}{l}\text { Sharma et } \\
(2016) \text { [121] }\end{array}$ & $\begin{array}{l}\text { Perspectives } \\
\text { Science }\end{array}$ & Q2 & $\begin{array}{l}\text { Since the ride comfort of the passengers on vehicles is of paramount } \\
\text { importance, a mechanical model of a train subjected to external loads } \\
\text { (rolling and longitudinal wheel resistance, and gravity) is considered. } \\
\text { The jerk value are measured and analysed. }\end{array}$ & $\begin{array}{l}\text { Jerk is considered as a criterion of } \\
\text { discomfort in this work. }\end{array}$ \\
\hline $\begin{array}{l}\text { Huang et al. } \\
(2018) \text { [109] }\end{array}$ & $\begin{array}{l}\text { International Journal } \\
\text { of Adaptive Control } \\
\text { Signal Processing }\end{array}$ & Q1 & $\begin{array}{l}\text { An anti-jerk controller for electromechanical clutch engagement was } \\
\text { developed in this work. }\end{array}$ & $\begin{array}{l}\text { Jerk as a limiting factor in designing } \\
\text { controllers in vehicles. Details of } \\
\text { these controllers are beyond the } \\
\text { scope of this work. }\end{array}$ \\
\hline $\begin{array}{l}\text { Batra et } \\
(2018)[101]\end{array}$ & $\begin{array}{l}\text { Journal of } \\
\text { Computational } \\
\text { Nonlinear Dynamics }\end{array}$ & Q2 & $\begin{array}{l}\text { An anti-jerk controller based on road tests is proposed for an electric } \\
\text { vehicle in this work. }\end{array}$ & $\begin{array}{l}\text { Jerk as a limiting factor in designing } \\
\text { controllers in vehicles. Details of } \\
\text { these controllers are beyond the } \\
\text { scope of this work. }\end{array}$ \\
\hline $\begin{array}{l}\text { Bae et } \\
(2019)[12]\end{array}$ & journal of Electronics & Q3 & $\begin{array}{l}\text { To provide a comfortable driving experience, while not sabotaging the } \\
\text { passengers' safety, on a self-driving shuttle bus. A time-optimal velocity } \\
\text { planning method to guarantee a comfort criteria was developed. A better } \\
\text { performance and comfortable passenger ride in a self-driving shuttle bus } \\
\text { is experienced. }\end{array}$ & $\begin{array}{l}\text { This is also aligned with the } \\
\text { application of jerk in ride comfort } \\
\text { and its potential to be considered in } \\
\text { autonomous cars. }\end{array}$ \\
\hline
\end{tabular}


Table 8. Cont.

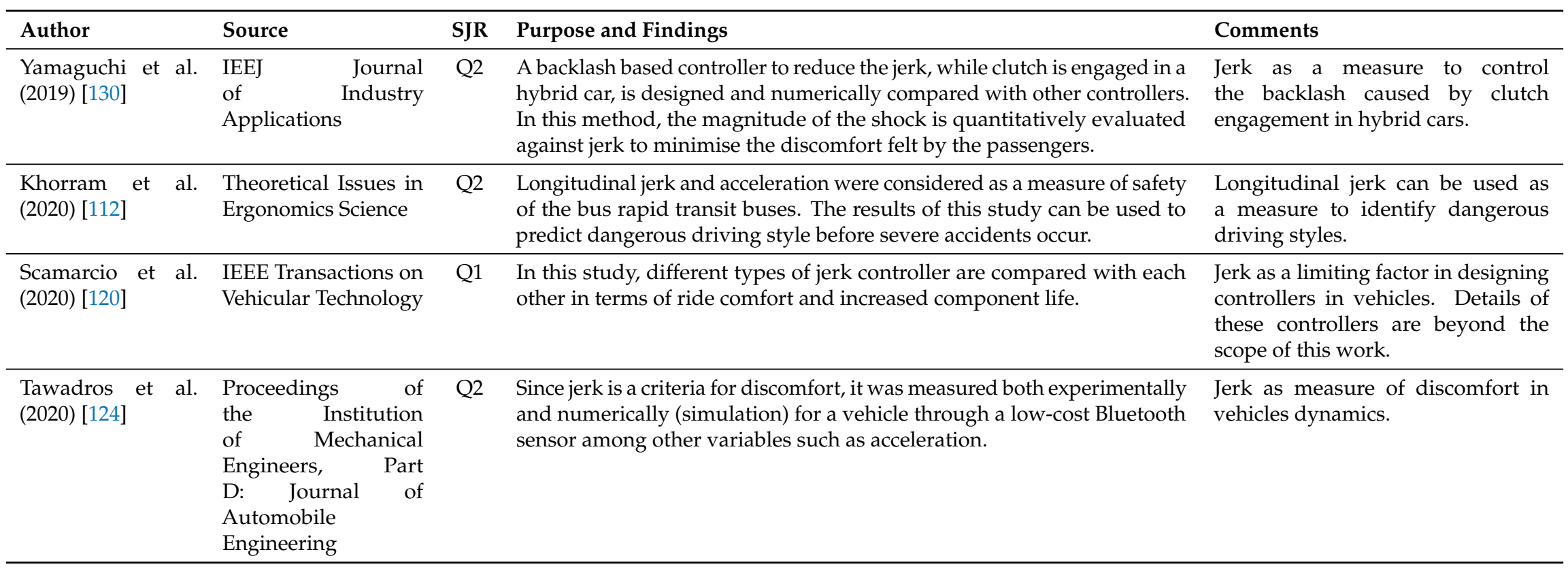


Table 9. Jerk in EOM.

\begin{tabular}{|c|c|c|c|c|}
\hline Author & Source & SJR & Purpose and Findings & Comments \\
\hline $\begin{array}{l}\text { Muszynska } \\
\& \quad \text { Bently } \\
(1990)[132,133]\end{array}$ & $\begin{array}{l}\text { Journal of Sound } \\
\text { Vibration \& NASA } \\
\text { technical report }\end{array}$ & Q1 & $\begin{array}{l}\text { Developing fluid force models in rotor/bearing/seal systems } \\
\text { and a fluid handling machine. Their results suggested that the } \\
\text { fluid force contains terms of orders higher than two. Specifically, } \\
\text { a third-order term (jerk) should be included. }\end{array}$ & $\begin{array}{l}\text { Jerk, as a higher order term, is } \\
\text { seen in the EOM of fluid model. }\end{array}$ \\
\hline $\begin{array}{l}\text { Inaudi et al. } \\
(1993)[134]\end{array}$ & $\begin{array}{l}\text { Earthquake } \\
\text { engineering } \\
\text { structural } \\
\text { dynamics }\end{array}$ & Q1 & $\begin{array}{l}\text { An optimum hybrid isolation system to protect sensitive } \\
\text { equipment from earthquake was designed, and the EOM of the } \\
\text { ground motion obtained. Jerk was a parameter in the ground } \\
\text { motion EOM. }\end{array}$ & $\begin{array}{l}\text { Jerk was mentioned in the model } \\
\text { of ground motion, which was } \\
\text { numerically modeled. }\end{array}$ \\
\hline $\begin{array}{l}\text { Funakoshi et al. } \\
\text { (2012) [135] }\end{array}$ & $\begin{array}{l}\text { ASME } 2012 \text { 5th } \\
\text { Annual Dynamic } \\
\text { Systems and } \\
\text { Control Conference } \\
\text { joint with the JSME } \\
2012 \text { 11th Motion } \\
\text { and Vibration } \\
\text { Conference }\end{array}$ & $\mathrm{N} / \mathrm{A}$ & $\begin{array}{l}\text { A modeling method and a control system design procedure for } \\
\text { a flexible rotor with many elastic modes using active magnetic } \\
\text { bearings is presented. A local jerk feedback control system and } \\
\text { stability analysis is developed by using root locus. }\end{array}$ & $\begin{array}{l}\text { It has been proposed to include } \\
\text { "jerk feedback" for rotors } \\
\text { suspended in active magnetic } \\
\text { bearings. In that case, jerk will } \\
\text { occur in the EOM. }\end{array}$ \\
\hline $\begin{array}{l}\text { Eager } \quad(2018) \\
{[136]}\end{array}$ & $\begin{array}{l}\text { Proceedings of } \\
\text { ACOUSTICS }\end{array}$ & $\mathrm{N} / \mathrm{A}$ & $\begin{array}{l}\text { A novel way of measuring jerk, snap and crackle using } \\
\text { accelerometers (while jumping on trampoline). The EOM of this } \\
\text { dynamic is obtained where jerk appears in the EOM. }\end{array}$ & $\begin{array}{l}\text { Jerk has appeared in the } \\
\text { obtained EOM of jumping on a } \\
\text { trampoline. }\end{array}$ \\
\hline
\end{tabular}


Table 10. Jerk in GPS application.

\begin{tabular}{|c|c|c|c|c|}
\hline Author & Source & SJR & Purpose and Findings & Comments \\
\hline $\begin{array}{l}\text { Kwon et al. } \\
(2006) \text { [137] }\end{array}$ & $\begin{array}{l}\text { Proceedings of the } \\
\text { Korean Institute } \\
\text { of Navigation } \\
\text { and Port Research } \\
\text { Conference }\end{array}$ & $\mathrm{N} / \mathrm{A}$ & $\begin{array}{l}\text { GPS used in satellite launch vehicles should perform under a } \\
\text { severe dynamic environment. Therefore, in this work, preliminary } \\
\text { test results of a GPS receiver in such simulated high acceleration } \\
\text { and jerk conditions are analysed. }\end{array}$ & $\begin{array}{l}\text { Jerk as a test parameter in testing } \\
\text { GPS used in satellite launch } \\
\text { vehicles. }\end{array}$ \\
\hline $\begin{array}{l}\text { Kwon et al. } \\
(2008)[138]\end{array}$ & $\begin{array}{l}\text { Proceedings of } \\
\text { the 17th World } \\
\text { Congress The } \\
\text { International } \\
\text { Federation of } \\
\text { Automatic Control }\end{array}$ & $\mathrm{N} / \mathrm{A}$ & $\begin{array}{l}\text { Comparative performance analyses of GPS receivers under } \\
\text { high-dynamic conditions. They used jerk as one of the parameters } \\
\text { of high-dynamic condition. The thresholds of GPS receiver } \\
\text { performance under severe dynamic condition were found to } \\
\text { be } 12.54 \mathrm{~m} / \mathrm{s} \text { for maximum velocity, } 16.07 \mathrm{~g} \text { for maximum } \\
\text { acceleration, and } 202.14 \mathrm{~g} / \mathrm{s} \text { for maximum jerk. The jerk level is } \\
\text { extremely high compared to the levels of velocity or acceleration. }\end{array}$ & $\begin{array}{l}\text { Jerk as a test parameter in testing } \\
\text { GPS used in satellite launch } \\
\text { vehicles. }\end{array}$ \\
\hline
\end{tabular}

Table 11. Jerk in human tolerance.

\begin{tabular}{|c|c|c|c|c|}
\hline Author & Source & SJR & Purpose and Findings & Comments \\
\hline $\begin{array}{l}\text { McKenney } \\
(1970)[203]\end{array}$ & Report & $\mathrm{N} / \mathrm{A}$ & $\begin{array}{l}\text { A literature review to study the human tolerance to abrupt } \\
\text { acceleration. Just as the slope of a velocity-time trace furnishes } \\
\text { acceleration, so the slope, or tangent, of an acceleration-time pulse } \\
\text { will yield rates of change in acceleration. They have studied } \\
\text { higher rates of onset, meaning jerk, snap, etc., and mentioned in } \\
\text { chapter } 4 \text { of the work that change of rate of acceleration is also } \\
\text { called jerk. }\end{array}$ & $\begin{array}{l}\text { A method to calculate jerk as } \\
\text { the slope of the acceleration-time } \\
\text { pulse plots was proposed. }\end{array}$ \\
\hline $\begin{array}{l}\text { Whinnery et al. } \\
\text { (2013) [202] }\end{array}$ & $\begin{array}{l}\text { Extreme } \\
\text { physiology } \\
\text { medicine }\end{array}$ & Q4 & $\begin{array}{l}\text { They referred to jerk as acceleration onset. This concussion curve } \\
\text { provides a temporal prediction of when the concussion might } \\
\text { occur. Jerk was referred to as acceleration onset rate. }\end{array}$ & $\begin{array}{l}\text { The jerk loss of concussion curve } \\
\text { was studied. }\end{array}$ \\
\hline
\end{tabular}


Table 12. Jerk in kinesiology.

\begin{tabular}{|c|c|c|c|c|}
\hline Author & Source & SJR & Purpose and Findings & Comments \\
\hline Fazio et al. (2013) [139] & Neurological Sciences & Q2 & $\begin{array}{l}\text { To evaluate the accelerometric parameters of human gait patterns in different } \\
\text { neurological conditions with pathological gait impairment compared to healthy } \\
\text { subjects. The acceleration and jerk data were used to compare different groups. } \\
\text { Analyses of the basic accelerometric parameters associated with a jerk analysis } \\
\text { could assist in differentiating between the population groups. }\end{array}$ & $\begin{array}{l}\text { The use of P-value is currently heavily } \\
\text { debated, see, e.g., The ASA Statement } \\
\text { ([207]) on P-values. However, this work } \\
\text { draws attention to using jerk in gait } \\
\text { analysis. }\end{array}$ \\
\hline Lapinski (2013) [140] & PhD thesis & $\mathrm{N} / \mathrm{A}$ & $\begin{array}{l}\text { In this PhD thesis titled A platform for high-speed bio-mechanical analysis using } \\
\text { wearable wireless sensors, it is shown that jerk was a good monitor of a baseball } \\
\text { pitcher's likelihood of tearing a tendon, while other parameters such as peak } \\
\text { acceleration could not show this. }\end{array}$ & $\begin{array}{l}\text { Jerk has the potential to monitor different } \\
\text { injury scenarios or dynamics which other } \\
\text { parameters such as peak acceleration are } \\
\text { unable to detect. }\end{array}$ \\
\hline Aguirre (2016) [141] & Master thesis & $\mathrm{N} / \mathrm{A}$ & $\begin{array}{l}\text { To evaluate the usage of measurement devices (accelerometer) in clinical setting, } \\
\text { and to validate the recorded what kinematic parameters can be accurately } \\
\text { measured by them. Measurement devices are a reliable tool in capturing the } \\
\text { kinematic parameters such as movement time, maximum acceleration, mean } \\
\text { acceleration, mean acceleration variability, and maximum jerk, and therefore } \\
\text { should be considered in clinical setting as a low-cost technology compared with } \\
\text { the more expensive motion-capturing technologies. }\end{array}$ & $\begin{array}{l}\text { Expensive motion-capturing } \\
\text { technologies can be replaced by } \\
\text { measurement devices in clinical settings. }\end{array}$ \\
\hline $\begin{array}{l}\text { Zhang et al. } \\
(2019)[142]\end{array}$ & $\begin{array}{l}\text { Automation } \\
\text { Construction }\end{array}$ & Q1 & $\begin{array}{l}\text { In more recent times Zhang et al. [142] used jerk as an indicator of physical exertion } \\
\text { and fatigue within the construction industry. They monitored the activity of a } \\
\text { bricklayer using an inertial measurement device device that allowed jerk to be } \\
\text { calculated. }\end{array}$ & Jerk as a measure to detect fatigue. \\
\hline $\begin{array}{l}\text { Washington et al. } \\
\text { (2020) [143] }\end{array}$ & $\begin{array}{l}\text { Journal of Sports } \\
\text { Sciences }\end{array}$ & Q1 & $\begin{array}{l}\text { To determine the influence of pelvis and torso angular jerk on the hand velocity, } \\
\text { which is a hitting performance indicator in female softball. Although the results } \\
\text { did not show a significant relationship between pelvis and torso angular jerk and } \\
\text { hand velocity, more research could be conducted on the "timing" of minimal jerk } \\
\text { through the acceleration phase to predict the angular hand velocity. }\end{array}$ & $\begin{array}{l}\text { Jerk, both its magnitude and duration, } \\
\text { should be studied more in sport science. }\end{array}$ \\
\hline
\end{tabular}


Table 13. Jerk in measurement.

\begin{tabular}{|c|c|c|c|c|}
\hline Author & Source & SJR & Purpose and Findings & Comments \\
\hline $\begin{array}{l}\text { Masuda et al. } \\
\text { (2002) [148] }\end{array}$ & $\begin{array}{l}\text { The Proceedings } \\
\text { of the Symposium } \\
\text { on Evaluation and } \\
\text { Diagnosis }\end{array}$ & $\mathrm{N} / \mathrm{A}$ & $\begin{array}{l}\text { A jerk-dot sensor, which measures the second derivative of the acceleration, } \\
\text { is developed. Its capability of detecting the local damage in the structural } \\
\text { members is investigated through low-cycle fatigue tests, which prove its significant } \\
\text { sensitivity to the abnormal responses due to the development of macroscopic } \\
\text { damages. Further fracture tests are carried out to obtain the correlation between } \\
\text { the measured jerk-dot and the crack length, which suggests that this sensor could } \\
\text { provide an early alert before the crack grows to the fatal stage. }\end{array}$ & $\begin{array}{l}\text { Comment by Iyama \& Wakui on this } \\
\text { paper [175]: "Although they found } \\
\text { that the high-frequency components } \\
\text { accompanying crack initiation by jerk } \\
\text { or jerk-dot can be used for detection, } \\
\text { only a qualitative relation was shown. } \\
\text { The determination of threshold values for } \\
\text { damage detection thus remains difficult." }\end{array}$ \\
\hline $\begin{array}{l}\text { Xueshan et al. } \\
\text { (2008) [150] }\end{array}$ & $\begin{array}{l}\text { Proceedings of the 14th } \\
\text { World Conference on } \\
\text { Earthquake Engineering }\end{array}$ & $\mathrm{N} / \mathrm{A}$ & $\begin{array}{l}\text { The principles and specifications of a new sensor for measuring jerk are given. } \\
\text { Derivative of acceleration is the first-order differentiation of acceleration. }\end{array}$ & $\begin{array}{l}\text { JW-3D tri-axial Jerk sensor. } \\
\text { The specifications of the jerk sensor } \\
\text { are provided. Xueshan Patents [150] } \\
\text { exist for jerk-meter, but it is not known } \\
\text { to what extent they are used in practice. }\end{array}$ \\
\hline $\begin{array}{l}\text { Manabe et al. } \\
(2018)[151]\end{array}$ & $\begin{array}{l}2018 \quad \text { International } \\
\text { Conference on } \\
\text { Advanced Mechatronic } \\
\text { Systems }\end{array}$ & $\mathrm{N} / \mathrm{A}$ & $\begin{array}{l}\text { A horizontal jerk sensor was produced by rebuilding a feedback circuit of a } \\
\text { commercially available velocity sensor. It was then applied to a linear slider for } \\
\text { mechanical impedance control. }\end{array}$ & $\begin{array}{l}\text { A jerk sensor is rebuilt using a } \\
\text { commercial velocity sensor. }\end{array}$ \\
\hline
\end{tabular}


Table 14. Jerk in motion analysis.

\begin{tabular}{|c|c|c|c|c|}
\hline Author & Source & SJR & Purpose and Findings & Comments \\
\hline $\begin{array}{l}\text { Thompson } \\
\text { (2012) [152] }\end{array}$ & $\begin{array}{l}\text { Jyväskylä studies in } \\
\text { humanities }\end{array}$ & $\mathrm{N} / \mathrm{A}$ & $\begin{array}{l}\text { Motion capture techniques were used to study music cognition, } \\
\text { in which Jerk is used a measure in machine learning classifiers. }\end{array}$ & $\begin{array}{l}\text { Jerk is considered in the } \\
\text { embodied music cognition } \\
\text { research. }\end{array}$ \\
\hline $\begin{array}{l}\text { Jongejan } \\
\text { (2017) [153] }\end{array}$ & $\begin{array}{l}\text { Proceedings of } \\
\text { the 4th European } \\
\text { and } 7 \text { th Nordic } \\
\text { Symposium } \\
\text { on Multimodal } \\
\text { Communication }\end{array}$ & $\mathrm{N} / \mathrm{A}$ & $\begin{array}{l}\text { Jerk is used a measure for support vector machine classifier, } \\
\text { used for classifying head movements, along with other measures } \\
\text { of velocity and acceleration. }\end{array}$ & $\begin{array}{l}\text { Jerk as a measure for machine } \\
\text { learning classifiers in motion } \\
\text { analysis application. }\end{array}$ \\
\hline
\end{tabular}

Table 15. Jerk in ornithology.

\begin{tabular}{|c|c|c|c|c|}
\hline Author & Source & SJR & Purpose and Finding & Comments \\
\hline $\begin{array}{l}\text { Sharker et al. } \\
\text { (2019) [154] }\end{array}$ & $\begin{array}{l}\text { Bio-inspiration } \\
\text { biometrics }\end{array}$ & Q1 & $\begin{array}{l}\text { To see why plunge diver birds can dive into water with high } \\
\text { speed while surface bird divers cannot and to see if there is a } \\
\text { correlation between this fact and physical geometry, mainly of } \\
\text { the beak. Since real experiments could not be conducted, they } \\
\text { used a 3D-printed model of three types of diving birds with } \\
\text { an embedded accelerometer. Surface diving birds have high } \\
\text { non-dimensional jerk }\left(J^{*}=(\Delta a \Delta t)[m /(\rho g v A)]\right) \text {, which is higher } \\
\text { than the recommended safe jerk limit (for humans/no data for } \\
\text { birds). }\end{array}$ & $\begin{array}{l}\text { The impact acceleration of } \\
\text { the bird models were not } \\
\text { distinguishable while the jerk } \\
\text { value was quite different. This } \\
\text { draws attention to the fact that } \\
\text { some dynamical behaviour } \\
\text { scenarios cannot be fully } \\
\text { captured by acceleration and } \\
\text { jerk should be considered in } \\
\text { such scenarios. }\end{array}$ \\
\hline
\end{tabular}


Table 16. Jerk in greyhound racing.

\begin{tabular}{|c|c|c|c|c|}
\hline Author & Source & SJR & Purpose and Finding & Comments \\
\hline $\begin{array}{l}\text { Hossain et al. } \\
(2016)[155]\end{array}$ & Report & $\mathrm{N} / \mathrm{A}$ & $\begin{array}{l}\text { The jerk was calculated from race track survey plans to identify } \\
\text { thresholds for a safe turn in racing greyhounds. }\end{array}$ & $\begin{array}{l}\text { Jerk is studied as a safety } \\
\text { threshold in greyhound racing } \\
\text { track bend design. }\end{array}$ \\
\hline $\begin{array}{l}\text { Hayati et al. } \\
(2017)[156]\end{array}$ & $\begin{array}{l}\text { ASME } 2017 \\
\text { International } \\
\text { Design Engineering } \\
\text { Technical } \\
\text { Conferences }\end{array}$ & $\mathrm{N} / \mathrm{A}$ & $\begin{array}{l}\text { High-jerk turning, which is caused by an inappropriate bend and } \\
\text { camber of race tracks, was given among the potential risk factors } \\
\text { causing injuries in racing greyhounds. }\end{array}$ & $\begin{array}{l}\text { Jerk is briefly mentioned in turn } \\
\text { transitions. }\end{array}$ \\
\hline $\begin{array}{l}\text { Hayati et al. } \\
(2017)[157]\end{array}$ & $\begin{array}{l}\text { 9th Australasian } \\
\text { Congress on } \\
\text { Applied Mechanics }\end{array}$ & $\mathrm{N} / \mathrm{A}$ & $\begin{array}{l}\text { High rates of injuries in racing greyhounds and the potential risk } \\
\text { factors were discussed. Turns with inappropriate transitions with } \\
\text { high jerks were mentioned as an important risk factor. }\end{array}$ & $\begin{array}{l}\text { Jerk is briefly mentioned as a risk } \\
\text { factor in the greyhound racing } \\
\text { industry. }\end{array}$ \\
\hline $\begin{array}{l}\text { Hayati et al. } \\
(2018)[158]\end{array}$ & $\begin{array}{ll}\text { ASME } & 2018 \\
\text { International } & \\
\text { Mechanical } & \\
\text { Engineering } & \\
\text { Congress } & \text { and } \\
\text { Exposition } & \end{array}$ & $\mathrm{N} / \mathrm{A}$ & $\begin{array}{l}\text { High-jerk turning, which is caused by an inappropriate bend and } \\
\text { camber of race tracks, was given among the potential risk factors } \\
\text { causing injuries in racing greyhounds. }\end{array}$ & $\begin{array}{l}\text { Jerk is briefly mentioned in turn } \\
\text { transitions. }\end{array}$ \\
\hline $\begin{array}{l}\text { Mahdavi et al. } \\
\text { (2018) [159] }\end{array}$ & $\begin{array}{ll}\text { ASME } & 2018 \\
\text { International } & \\
\text { Mechanical } & \\
\text { Engineering } & \\
\text { Congress } & \text { and } \\
\text { Exposition } & \end{array}$ & $\mathrm{N} / \mathrm{A}$ & $\begin{array}{l}\text { High-jerk turning, which is caused by an inappropriate bend and } \\
\text { camber of race tracks, was given among the potential risk factors } \\
\text { causing injuries in racing greyhounds. }\end{array}$ & $\begin{array}{l}\text { Jerk is briefly mentioned in turn } \\
\text { transitions. }\end{array}$ \\
\hline $\begin{array}{l}\text { Hossain et al. } \\
(2020)[160]\end{array}$ & Scientific Reports & Q1 & $\begin{array}{l}\text { Designing a racing greyhound ideal trajectory path to minimise } \\
\text { the injuries. This ideal trajectory path is based on minimum jerk } \\
\text { rate. }\end{array}$ & $\begin{array}{l}\text { Confirms the significance of jerk } \\
\text { in racing. }\end{array}$ \\
\hline
\end{tabular}


Table 17. Jerk in sea-keeping.

\begin{tabular}{|c|c|c|c|c|}
\hline Author & Source & SJR & Purpose and Findings & Comments \\
\hline Tomi (1961) [126] & $\begin{array}{l}\text { The Japan Society of } \\
\text { Naval Architects and } \\
\text { Ocean Engineering }\end{array}$ & $\mathrm{N} / \mathrm{A}$ & $\begin{array}{l}\text { Ride comfort of passengers on ships was studied. The influence of jerk on the } \\
\text { rolling motion was discovered. }\end{array}$ & $\begin{array}{l}\text { One of the first references considered } \\
\text { jerk in ride comfort in sea-keeping. Jerk } \\
\text { is referred to as the time derivative of } \\
\text { acceleration. }\end{array}$ \\
\hline $\begin{array}{l}\text { Shigehiro et al. } \\
\text { (2002) [122] }\end{array}$ & Fisheries science & Q3 & $\begin{array}{l}\text { The new evaluation method of passenger comfort is expressed by vertical and } \\
\text { lateral accelerations, and exposure duration represents the relationship between } \\
\text { ship motions and seasickness. It is confirmed that the correlation coefficient } \\
\text { between the results of the new method and the questionnaires given to the trainees } \\
\text { show fairly similar results. }\end{array}$ & $\begin{array}{l}\text { Jerk is not directly mentioned. Only } \\
\text { the work conducted by Tomi [126] was } \\
\text { briefly mentioned. }\end{array}$ \\
\hline $\begin{array}{l}\text { Railey et al. } \\
\text { (2016) [8] }\end{array}$ & Report & $\mathrm{N} / \mathrm{A}$ & $\begin{array}{l}\text { The aim of this work was to provide a universal guidance for the measurement } \\
\text { and analysis of recorded acceleration data in high-speed crafts for different } \\
\text { organisation. Four visual observations to conclude that acceptable low-pass } \\
\text { filtering of an acceleration record has been achieved were proposed (i.e., no } \\
\text { over-filtering). One of the proposed observations was that the rate of acceleration } \\
\text { application (i.e., jerk) of the filtered record is approximately the same as the } \\
\text { unfiltered record. }\end{array}$ & $\begin{array}{l}\text { The value of jerk was used to assess the } \\
\text { accountability of filter acceleration data } \\
\text { using a low pass filter. }\end{array}$ \\
\hline $\begin{array}{l}\text { Sosa \& Ooms } \\
(2016)[9]\end{array}$ & Report & $\mathrm{N} / \mathrm{A}$ & $\begin{array}{l}\text { The role of roll stabiliser in the ride comfort in the yacht industry is analysed. Jerk } \\
\text { is mentioned as a ride comfort parameter but was not included in the ride comfort } \\
\text { rating used in this study. Since it is seen in the literature that jerk is an important } \\
\text { parameter in this respected, further research in including jerk in the yacht ride } \\
\text { comfort rating is critical. }\end{array}$ & $\begin{array}{l}\text { Points at the need for more studies of the } \\
\text { effect of jerk in yacht industry. }\end{array}$ \\
\hline $\begin{array}{l}\text { Coats \& Riley } \\
(2018)[204]\end{array}$ & $\begin{array}{l}\text { Naval Surface Warfare } \\
\text { Center technical report }\end{array}$ & $\mathrm{N} / \mathrm{A}$ & $\begin{array}{l}\text { The preliminary guidance for laboratory testing of marine shock isolation seats } \\
\text { is given in this report. Jerk was among those parameters considered in the shock } \\
\text { severity analysis. }\end{array}$ & $\begin{array}{l}\text { The importance of jerk in the shock } \\
\text { severity analysis in high-speed craft. }\end{array}$ \\
\hline Werkman (2019) [10] & Master thesis & $\mathrm{N} / \mathrm{A}$ & To study the impact of jerk on comfort of passengers in sea-keeping. & $\begin{array}{l}\text { Points at the need for more studies of the } \\
\text { effect of jerk. Importance of jerk in sea } \\
\text { keeping and ride comfort in general. }\end{array}$ \\
\hline
\end{tabular}




\subsection{Jerk in Seismic Analysis}

Seismic analysis is a subset of structural analysis and is the calculation of the response of a building structure to earthquakes. It is part of the process of structural design, earthquake engineering or structural assessment and retrofit in regions where earthquakes are prevalent [134,161-170] (Table 18).

\subsection{Jerk in Shock Response Spectrum}

Equipment that is delivered to naval ships needs to be shockproof. The basic philosophy is that the equipment should withstand the same explosions as the ship itself (it would be unfortunate if the ship survived the blast, while it were impossible to operate since all equipment has been destroyed). Preferably, the shock-proofness of the equipment should be verified both theoretically and experimentally.

There are essentially three methods for theoretical verification, including:

- Static calculation, where you assume inertia forces of the mass times g in various directions;

- Calculation with shock response spectrum;

- Integration in the time domain.

Static calculations are easiest to carry out. In these calculations, neither the shape of the time history of the shock (e.g., blast or earthquake) nor the dynamic properties of the equipment under consideration (e.g., resonance frequencies) are taken into account. This means that you should normally have a considerable safety margin.

The shock response spectrum was invented by the Flemish-American engineer Maurice Anthony Binot (1905-1985). The basic idea is to draw a diagram that shows the maximum acceleration and relative displacement for a number of single-mass oscillators with various eigen frequencies for a certain shock time history. Normally, a simplified curve is drawn that might be an envelope for several time histories. This curve can be used to calculate the maximum amplitude for each eigenmode of the real equipment, and finally the contributions of each eigenmode can be added. There are different ways to add the contributions from the eigenmodes depending on how cautious you are. The very conservative approach is that you assume that, at some point in time, all the contributions of the eigenmodes are pointing in the same direction. This curve can not be used for testing, so a new time history curve has to be synthesised as input to that activity. It is out of the scope of this article to discuss details of this method, but it is interesting to point out that in these calculations jerk, etc., are implicitly taken into account.

The most straightforward method to carry out shock calculations is by integration in the time domain. Since the calculations are based on the time history, the derivatives of the acceleration are implicitly taken into account. The time history can, of course, directly be used as input to the test activity and comparison between calculations and measurements should be straightforward. The main drawback of this method is that it consumes a lot of computer power.

Studies that studied jerk in shock responses are listed in Table 19.

\subsection{Jerk in Sport Science}

Sport science is a general term which can include the science behind designing running shoes and studying the impact attenuation properties of greyhound's surface. Those articles that passed the inclusion criteria of this work are tabulated in Table 20.

\subsection{Jerk in Structural Health Monitoring}

Vibration monitoring is another challenging area, e.g., it would be beneficial to be able to be able to identify the wear on gearboxes of wind power stations in due time. However, the application of higher-order derivatives of acceleration for damage detection requires further investigation. Using jerk as one parameter to be monitored has been suggested, e.g., by Zhang et al. (2012) [174] (Table 21). 
Table 18. Jerk in seismic analysis.

\begin{tabular}{|c|c|c|c|c|}
\hline Author & Source & SJR & Purpose and Findings & Comments \\
\hline $\begin{array}{l}\text { Malushte } \\
\text { (1987) [161] }\end{array}$ & Master thesis & $\mathrm{N} / \mathrm{A}$ & $\begin{array}{l}\text { To predict the seismic design response spectra using ground } \\
\text { characteristics. A single-degrees-of-freedom (SDOF) is used to study } \\
\text { the ground motion characteristics, such as as peak displacement, velocity, } \\
\text { acceleration and root mean square acceleration. The average value of } \\
\text { the ratio of the maximum jerk to the maximum ground acceleration and } \\
\text { maximum ground velocity to the maximum ground displacement are } \\
\text { given. These values are required when the prediction of the relative } \\
\text { velocity spectra from the pseudo velocity spectra is of interest. }\end{array}$ & $\begin{array}{l}\text { Jerk is briefly mentioned in this } \\
\text { work. }\end{array}$ \\
\hline $\begin{array}{l}\text { Inaudi et al. } \\
\text { (1993) [134] }\end{array}$ & $\begin{array}{l}\text { Earthquake } \\
\text { engineering } \\
\text { structural dynamics }\end{array}$ & Q1 & $\begin{array}{l}\text { An optimum hybrid isolation system to protect sensitive equipment from } \\
\text { earthquake was designed and the EOM of the ground motion obtained. } \\
\text { Jerk was a parameter in the ground motion EOM. }\end{array}$ & $\begin{array}{l}\text { Jerk was mentioned in the model } \\
\text { of of ground motion, which was } \\
\text { numerically modeled. }\end{array}$ \\
\hline $\begin{array}{l}\text { Bertero et al. } \\
(2002)[162]\end{array}$ & $\begin{array}{l}\text { Earthquake } \\
\text { engineering } \\
\text { structural dynamics }\end{array}$ & Q1 & $\begin{array}{l}\text { Different objectives were given for this work but one of the main objective } \\
\text { was to review the understanding of performance-based-seismic-design } \\
\text { (PBSD), the requirements for a reliable PBSD, and finally to study why } \\
\text { some designs fail to satisfy those requirement. Jerk was mentioned as } \\
\text { a useful parameter which should be taken into consideration for such } \\
\text { designs, mainly in the case of frequent minor earthquake ground motions. }\end{array}$ & $\begin{array}{l}\text { Jerk is mentioned as a useful } \\
\text { parameter for reliable PBSD design, } \\
\text { mainly in the case of frequent minor } \\
\text { earthquake ground motion. }\end{array}$ \\
\hline $\begin{array}{l}\text { Geoffrey et al. } \\
\text { (2003) [163] }\end{array}$ & $\begin{array}{l}\text { Earthquake } \\
\text { engineering } \\
\text { structural dynamics }\end{array}$ & Q1 & $\begin{array}{l}\text { To regulate the total structural jerk to manage the structural energy and } \\
\text { enhancing the performance of civil structures undergoing large seismic } \\
\text { events. This new method used in this work is preferred over conventional } \\
\text { methods. Their proposed jerk regulation control method is shown to have } \\
\text { better performance than typical structural control methods for near-field } \\
\text { seismic events where the response is dominated by a large impulse. }\end{array}$ & $\begin{array}{l}\text { Importance of jerk in seismic control } \\
\text { of a civil structure which has benefits } \\
\text { over the conventional method. }\end{array}$ \\
\hline $\begin{array}{l}\text { Tong et al. } \\
(2005)[164]\end{array}$ & $\begin{array}{l}\text { Earthquake } \\
\text { Engineering } \\
\text { and Engineering } \\
\text { Vibration }\end{array}$ & Q2 & $\begin{array}{l}\text { The importance of jerk in seismic motion analysis is not extensively } \\
\text { studied. Therefore, they studied the basic characteristics of time } \\
\text { derivatives of acceleration (TdoA) on records from the } 1999 \text { Chi-Chi, } \\
\text { earthquake (Mw 7.6) and one of its aftershocks (Mw 6.2). }\end{array}$ & $\begin{array}{l}\text { Highlighted the importance of jerk } \\
\text { (referred to it as TDoA) is seismic } \\
\text { motion analysis. }\end{array}$ \\
\hline
\end{tabular}


Table 18. Cont.

\begin{tabular}{|c|c|c|c|c|}
\hline Author & Source & SJR & Purpose and Findings & Comments \\
\hline $\begin{array}{lrr}\text { He } & \text { et } & \text { al. } \\
(2015) & {[165]}\end{array}$ & Shock and Vibration & Q2 & $\begin{array}{l}\text { Jerk and its response spectra can improve the recognition of } \\
\text { non-stationary ground motion. Therefore, in this work, the jerk response } \\
\text { spectra for elastic and in-elastic system are characterised. }\end{array}$ & $\begin{array}{l}\text { It is mentioned that though jerk is an } \\
\text { important characteristic of ground } \\
\text { motion, it is not thoroughly studied } \\
\text { in seismic motion analysis. }\end{array}$ \\
\hline $\begin{array}{l}\text { Chakraborty } \\
\text { and } \\
\text { Ray-Chaudhuri } \\
\text { (2017) [166] }\end{array}$ & $\begin{array}{l}\text { Journal } \\
\text { Engineering } \\
\text { Mechanics }\end{array}$ & Q2 & $\begin{array}{l}\text { To study the energy transfer to a high-frequency mode of a building due } \\
\text { to a sudden change in stiffness at its base during seismic excitation. Jerk } \\
\text { was used to excite the structure. }\end{array}$ & $\begin{array}{l}\text { Jerk is used for exciting the structure } \\
\text { due to the fact that it is one of the } \\
\text { characteristics of ground motion. }\end{array}$ \\
\hline $\begin{array}{l}\text { Sofronie et al. } \\
\text { (2017) [170] }\end{array}$ & $\begin{array}{l}\text { Journal of Geological } \\
\text { Resource Engineering } \\
\text { with Computers }\end{array}$ & $\mathrm{N} / \mathrm{A}$ & The concept of jerk is extended in seismic engineering. & $\begin{array}{l}\text { Jerk in the context of seismic analysis } \\
\text { is discussed. }\end{array}$ \\
\hline $\begin{array}{l}\text { Taushanov } \\
\text { (2018) [167] }\end{array}$ & $\begin{array}{l}\text { Journal } \\
\text { Engineering } \\
\text { Mechanics }\end{array}$ & $\mathrm{N} / \mathrm{A}$ & $\begin{array}{l}\text { Excessive "jerky motion" affects comfort in building and bridges, and } \\
\text { therefore attempts to reduce this phenomenon should be taken into } \\
\text { consideration in engineering design. A jerk response spectra is given, } \\
\text { which should be considered in seismic analysis of a structure. }\end{array}$ & $\begin{array}{l}\text { Jerk spectra features is studied for } \\
\text { elastic and in-elastic systems. }\end{array}$ \\
\hline $\begin{array}{l}\text { Papandreou } \\
\text { and } \\
\text { Papagianno- } \\
\text { poulos } \\
(2019)[168]\end{array}$ & $\begin{array}{l}\text { Soil Dynamics } \\
\text { Earthquake } \\
\text { Engineering }\end{array}$ & Q1 & $\begin{array}{l}\text { To extract/study the general feature of jerk spectera for different seismic } \\
\text { motion scenarios. They used this method for in-elastic SDOF systems. } \\
\text { An empirical formula that provides jerk estimate for in-elastic SDOF } \\
\text { system is proposed for the first time in the literature (by the Bilinear, } \\
\text { the Ramberg-Osgood and the Takeda hysteresis rules). }\end{array}$ & $\begin{array}{l}\text { This shows the importance of jerk in } \\
\text { earthquake engineering. }\end{array}$ \\
\hline $\begin{array}{l}\text { Yaseen et al. } \\
(2020 \text { [169] }\end{array}$ & $\begin{array}{l}\text { Soil Dynamics } \\
\text { Earthquake } \\
\text { Engineering }\end{array}$ & $\mathrm{N} / \mathrm{A}$ & $\begin{array}{l}\text { The performance of jerk and its higher derivatives (referred to as relevant } \\
\text { derived parameters) to address the ground motion intensity in masonry } \\
\text { building was studied. }\end{array}$ & $\begin{array}{l}\text { Jerk was used as an intensity } \\
\text { measure in Seismic analysis of } \\
\text { masonry buildings. }\end{array}$ \\
\hline
\end{tabular}


Table 19. Jerk in shock response spectrum.

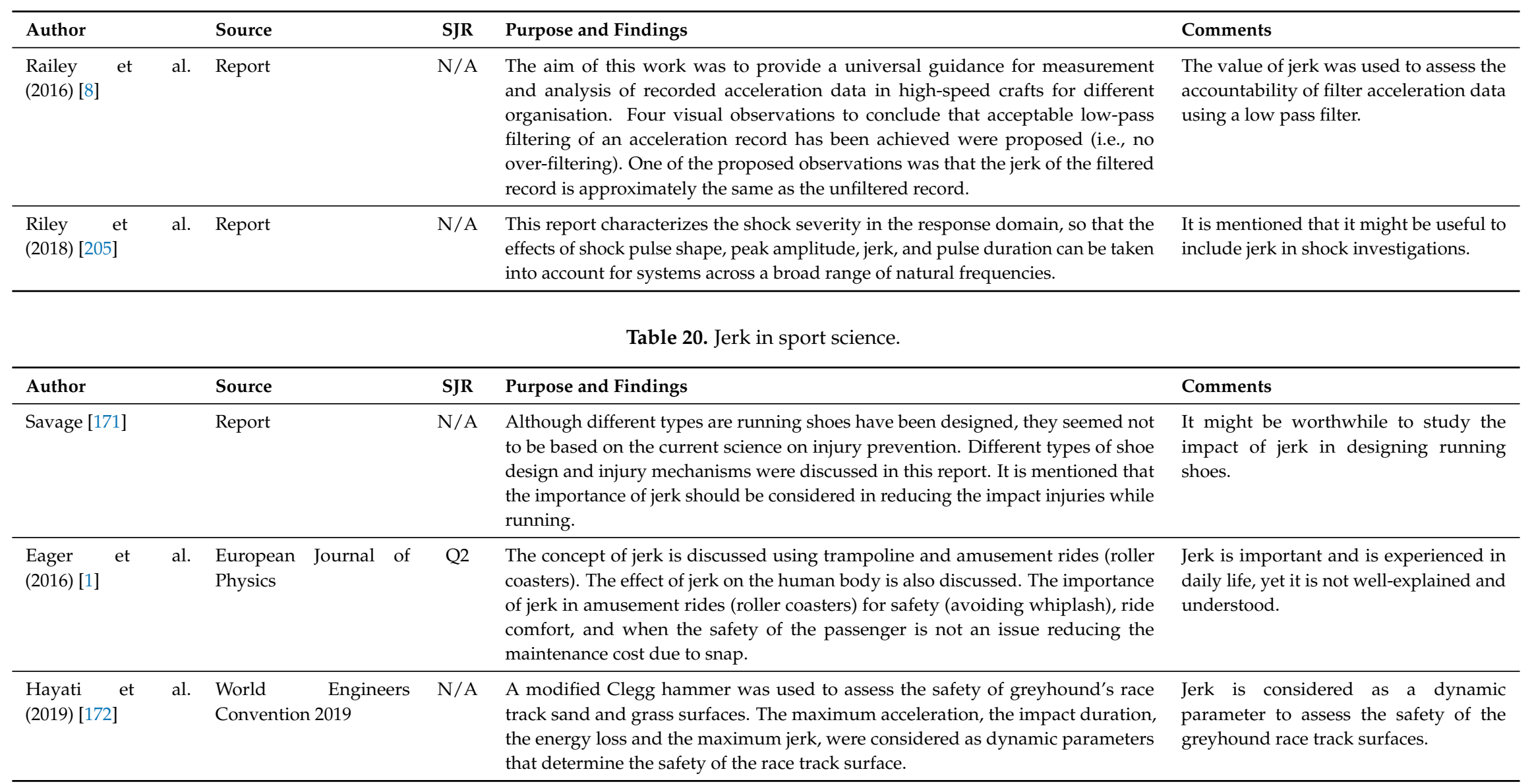


Table 21. Jerk in structural health monitoring.

\begin{tabular}{|c|c|c|c|c|}
\hline Author & Source & SJR & Purpose and Findings & Comments \\
\hline $\begin{array}{l}\text { Sone } \\
(2004)[173]\end{array}$ & $\begin{array}{l}\text { Journal of } \\
\text { Transactions of } \\
\text { Nippon Kikai } \\
\text { Gakkai Ronbunshu } \\
\text { C Hen }\end{array}$ & $\mathrm{N} / \mathrm{A}$ & $\begin{array}{l}\text { A statistical and data mining approach are applied on } \\
\text { time-domain jerk data in wind turbine gearboxes to detect } \\
\text { damage/failure. The appoach seemed promising in health } \\
\text { monitoring and is suggested to be expanded to the other parts of } \\
\text { the turbine as well. }\end{array}$ & $\begin{array}{l}\text { Jerkdot should be another } \\
\text { name for jounce/snap and is } \\
\text { mentioned in this work. This } \\
\text { work contains a description of } \\
\text { a "jounce meter". It is not clear } \\
\text { to what extent they are used in } \\
\text { practice. }\end{array}$ \\
\hline $\begin{array}{l}\text { Zhang et al. } \\
(2012)[174]\end{array}$ & $\begin{array}{l}\text { IEEE transactions } \\
\text { on energy } \\
\text { conversion }\end{array}$ & Q1 & $\begin{array}{l}\text { Fault analysis and health monitoring of the wind turbine gearbox } \\
\text { were the interests of this work. A statistical and data mining } \\
\text { approach are applied on time-domain jerk data in wind turbine } \\
\text { gearboxes to detect damage/failure. }\end{array}$ & $\begin{array}{l}\text { The approach seemed promising } \\
\text { in health monitoring and is } \\
\text { suggested to be expanded to the } \\
\text { other parts of the turbine as well. }\end{array}$ \\
\hline $\begin{array}{l}\text { Iyama et al. } \\
(2019)[175]\end{array}$ & $\begin{array}{l}\text { Japan Architectural } \\
\text { Review }\end{array}$ & $\mathrm{N} / \mathrm{A}$ & $\begin{array}{l}\text { To extend the nonlinear behaviour detection by determining the } \\
\text { mathematical model relation between the snap, stiffness change, } \\
\text { and the velocity of the vibration system. It is discussed that there } \\
\text { is lack of proper understanding of jerk and its higher derivative } \\
\text { in the field. }\end{array}$ & $\begin{array}{l}\text { Higher derivatives of jerk, } \\
\text { mainly snap, can be used to } \\
\text { detect nonlinearity in structural } \\
\text { health monitoring methods. }\end{array}$ \\
\hline $\begin{array}{l}\text { Sumathy et al. } \\
(2019)[176]\end{array}$ & $\begin{array}{l}\text { Cogent } \\
\text { Engineering }\end{array}$ & Q2 & $\begin{array}{l}\text { Fault diagnosis of wind turbine gear was investigated in this } \\
\text { work. They proposed a novel method of analysing the stability } \\
\text { of Interacting Multiple Model (IMM) algorithm for a linear } \\
\text { system (the details of this methodare out of scope of this review } \\
\text { article.) They mentioned that analysing jerk data coming from the } \\
\text { vibration of acceleration data via the IMM Kalman filter is a novel } \\
\text { endeavor to the best of their knowledge. }\end{array}$ & $\begin{array}{l}\text { Jerk can be used in health } \\
\text { monitoring of dynamical system. }\end{array}$ \\
\hline
\end{tabular}




\subsection{Jerk in Technical Pain}

Jerk was used to expand the understanding of researcher of sensed pain via a pain sensor where jerk was used as a biometric measure (Table 22).

\subsection{Jerk in $U A V$}

Jerk, and even higher derivatives of it (aka jounce/snap), have been recently used in designing, testing and controlling UAVs [11,178-186] (Table 23).

\subsection{Jerk in Vehicles-Land Based Traditional}

Jerk in vehicles is mainly used for measuring the ride comfort $[12,25,45,95,98-106,108,109,111-113$, $115,118-121,123-125,127-131]$. It is also used as a controller design, referred to as an anti-jerk controller design $[95,98-102,109,111,119,120,130]$. Jerk is also used in autonomous vehicles $[12,114,123,187,188]$, which is explained in the below sections.

\subsubsection{Jerk in Vehicles: Ride Comfort}

One of the main applications of jerk in vehicles is as criteria for discomfort. Details of these studies were given in Table 7 .

\subsubsection{Jerk in Vehicles: Autonomous Vehicles}

Jerk in autonomous driving is used to evaluate the comfortable ride and safety of the passengers $[12,114,123,187,188]$ (Table 24). 
Table 22. Jerk in technical pain.

\begin{tabular}{|c|c|c|c|c|}
\hline Author & Source & SJR & Purpose and Findings & Comments \\
\hline $\begin{array}{l}\text { Ostermeyer et al. } \\
(2008) \text { [177] }\end{array}$ & $\begin{array}{l}\text { Applied Mechanics } \\
\text { and Materials }\end{array}$ & $\mathrm{N} / \mathrm{A}$ & $\begin{array}{l}\text { The concept of technical pain, which is based on the analysis of } \\
\text { mesoscopic systems, was introduced in this work. The system } \\
\text { was modeled as damped oscillators and the heat transferred by } \\
\text { an impact. Pain was defined as an integral over the square of } \\
\text { jerk. They developed a pain sensor and used it to analyse the pain } \\
\text { caused by different types of signals. }\end{array}$ & $\begin{array}{l}\text { Jerk used to obtain a measure } \\
\text { of pain and used in the } \\
\text { development of a pain sensor. }\end{array}$ \\
\hline
\end{tabular}

Table 23. Jerk in UAV.

\begin{tabular}{|c|c|c|c|c|}
\hline Author & Source & SJR & Purpose and Finding & Comments \\
\hline $\begin{array}{l}\text { Luukkonen } \\
\text { (2011) [181] }\end{array}$ & $\begin{array}{l}\text { Independent research } \\
\text { project in applied } \\
\text { mathematics }\end{array}$ & $\mathrm{N} / \mathrm{A}$ & $\begin{array}{l}\text { To model and control the quadcopter. It is found that high snap values } \\
\text { will contribute to high control input values, and therefore the jounces } \\
\text { have to be considered closely when generating the accelerations. }\end{array}$ & $\begin{array}{l}\text { Jounce/snap is considered in } \\
\text { modelling and controlling the } \\
\text { quadcopter. Not only jerk, but also } \\
\text { snap (jounce), may be relevant in } \\
\text { the design and control of the drone. }\end{array}$ \\
\hline $\begin{array}{l}\text { Rakgowa et al. } \\
\text { (2015) [183] }\end{array}$ & $\begin{array}{l}\text { EEE International } \\
\text { Symposium on } \\
\text { Robotics and } \\
\text { Intelligent Sensors }\end{array}$ & $\mathrm{N} / \mathrm{A}$ & $\begin{array}{l}\text { A minimum-jerk trajectory controllers was developed for a quadrotor } \\
\text { during high-acceleration dynamics, e.g., lift-off. }\end{array}$ & $\begin{array}{l}\text { Jerk as a measure to generate } \\
\text { trajectories in UAVs. }\end{array}$ \\
\hline $\begin{array}{l}\text { Phang et al. } \\
(2015)[182]\end{array}$ & Mechatronics & Q1 & $\begin{array}{l}\text { In an UAV calligraphy project, having a smooth trajectory control was } \\
\text { desired. Accordingly, jerk was used as a limiting parameter to generate } \\
\text { smooth trajectories. }\end{array}$ & $\begin{array}{l}\text { Jerk as a measure to generate } \\
\text { trajectories in UAVs. }\end{array}$ \\
\hline $\begin{array}{l}\text { Fiori et } \\
(2016)[178]\end{array}$ & $\begin{array}{l}\text { The 10th } \\
\text { International } \\
\text { Conference on } \\
\text { Circuits, Systems, } \\
\text { Signals and } \\
\text { Telecommunications }\end{array}$ & $\mathrm{N} / \mathrm{A}$ & $\begin{array}{l}\text { Use of jerk (referred to as lurch index) to assess the drone's attitude } \\
\text { fluency maneuverability. It is found that the geometric lurch index is } \\
\text { fairly sensitive to the fluency of attitude maneuvering. }\end{array}$ & Uses the term "lurch index". \\
\hline
\end{tabular}


Table 23. Cont.

\begin{tabular}{|c|c|c|c|c|}
\hline Author & Source & SJR & Purpose and Finding & Comments \\
\hline $\begin{array}{l}\text { Nemes \& Mester } \\
\text { (2016) [11] }\end{array}$ & $\begin{array}{l}\text { The 4th International } \\
\text { Scientific Conference } \\
\text { on Advances } \\
\text { in Mechanical, } \\
\text { Engineering }\end{array}$ & $\mathrm{N} / \mathrm{A}$ & $\begin{array}{l}\text { Jerk is used as a parameter in controlling a drone. It is discussed that } \\
\text { an abrupt jerk induces vibrations and, in the case of vehicles, it would } \\
\text { negatively affect the ride comfort. }\end{array}$ & Use of jerk in controlling a drone. \\
\hline $\begin{array}{lr}\text { Silva et } & \text { al. } \\
(2018)[185] & \end{array}$ & Unmanned Systems & Q2 & $\begin{array}{l}\text { Controlling drones in a high-wind scenario and during thrust was a } \\
\text { challenge in this study. Accordingly, a jerk-minimum trajectory controller } \\
\text { was developed to optimise the motion. }\end{array}$ & $\begin{array}{l}\text { Jerk as a limiting parameter in } \\
\text { trajectory controllers. }\end{array}$ \\
\hline Guye (2018) [179] & Masters thesis & $\mathrm{N} / \mathrm{A}$ & $\begin{array}{l}\text { An Indoor multi-rotor test-bed for experimentation on autonomous } \\
\text { guidance strategies is developed. It is found that the jerk would minimize } \\
\text { the product of the control inputs, which are the major force that consume } \\
\text { the power energy of the drone. Consequently, minimizing these control } \\
\text { inputs will also reduce the power consumption. As a result, minimising } \\
\text { the jerk results in minimising the power consumption. }\end{array}$ & $\begin{array}{l}\text { Use of jerk in designing a test bed } \\
\text { for a drone. Since jerk minimisation } \\
\text { minimises the energy consumption, } \\
\text { it should be considered in drone } \\
\text { designs and controlling. }\end{array}$ \\
\hline $\begin{array}{l}\text { Rousseau et al. } \\
\text { (2018) [184] }\end{array}$ & $\begin{array}{l}\text { European Control } \\
\text { Conference }\end{array}$ & $\mathrm{N} / \mathrm{A}$ & $\begin{array}{l}\text { Minimum jerk trajectories and piece-wise polynomial trajectories are } \\
\text { used for cinematographic flight plans of a quadcopter. }\end{array}$ & $\begin{array}{l}\text { Jerk as a measure to generate } \\
\text { trajectories. }\end{array}$ \\
\hline $\begin{array}{l}\text { Lai et } \\
\text { (2019) }[180]\end{array}$ & $\begin{array}{l}\text { Frontiers of } \\
\text { Information } \\
\text { Technology } \\
\& \quad \text { Electronic } \\
\text { Engineering }\end{array}$ & Q2 & $\begin{array}{l}\text { To have a safe flying corridor, jerk limit ted trajectories were used in } \\
\text { real-time scenarios. }\end{array}$ & $\begin{array}{l}\text { Jerk as a limiting parameter in } \\
\text { trajectory controllers. }\end{array}$ \\
\hline
\end{tabular}


Table 24. Jerk in autonomous vehicles.

\begin{tabular}{|c|c|c|c|c|}
\hline Author & Source & SJR & Purpose and Findings & Comments \\
\hline $\begin{array}{l}\text { Bae et al. } \\
(2019)[12]\end{array}$ & $\begin{array}{l}\text { journal } \\
\text { Electronics }\end{array}$ & Q3 & $\begin{array}{l}\text { To provide a comfortable driving experience, while not sabotaging } \\
\text { the passengers' safety on a self-driving shuttle bus, a time-optimal } \\
\text { velocity planning method to guarantee a comfort criteria was } \\
\text { developed. A better performance and comfortable passenger ride } \\
\text { in the self-driving shuttle bus is experienced. }\end{array}$ & $\begin{array}{l}\text { This is also aligned with the } \\
\text { application of jerk in ride } \\
\text { comfort and its potential to be } \\
\text { considered in autonomous cars. }\end{array}$ \\
\hline $\begin{array}{l}\text { Krüger } \\
(2019) \text { [114] }\end{array}$ & Master thesis & $\mathrm{N} / \mathrm{A}$ & $\begin{array}{l}\text { To implement and evaluate a motion planner to find a rough speed } \\
\text { profile in autonomous cars. The value of jerk was considered as } \\
\text { passengers' ride comfort and safety measures. }\end{array}$ & $\begin{array}{l}\text { Points at the importance of } \\
\text { low-jerk trajectories to guarantee } \\
\text { passenger's safety and ride } \\
\text { comfort. }\end{array}$ \\
\hline
\end{tabular}




\section{Conclusions}

The purpose of this work was to show the importance of jerk in the context of science and engineering, by conducting a thorough systematic review of recent academic articles (2015-2020) where the term 'jerk' was mentioned in the title. The quality of papers was assessed based on Scientific Journal Rankings (SJR)—Scimago index, from the quartiles Q1 to Q4, where Q1 is occupied by the top $25 \%$ of journals, Q2 by the top $25 \%$ to $50 \%$, and so on. The articles were then categorised based on the application of jerk in twenty categories. The result of this systematic review showed that, although jerk is overlooked in secondary and higher education, jerk is ubiquitous. Road, rail and sea all have examples of a jerk, from crack initiation to ride comfort. Traditional printing and 3D-printing control systems all contain examples of a jerk. This review has provided a solid foundation for future research on the importance of jerk in different fields. It has identified research gaps which will assist researchers in creating a concise road map toward a more comprehensive study on jerk. The authors also emphasize that jerk is still essentially overlooked in secondary and higher education. This review provides support for teachers and textbook authors who may wish to include examples of jerk in their lessons and textbooks.

Jerk is all around as if we care to listen, feel, open our eyes and observe-from greyhound tracks to roller coasters.

Author Contributions: H.A. performed an initial literature search, including historical sources, and also followed up on some references in more detail through contacts with authors. A.-M.P. and D.E., following a collaboration of jerk in trampolines and roller coasters, initiated the research into jerk with a STEM educational context. D.E. suggested a more systematic literature review. H.H. did most of the searching, categorization and writing Conceptualization, H.H., D.E., A.-M.P. and H.A.; methodology, H.H. and D.E.; validation, H.H., D.E., A.-M.P. and H.A.; formal analysis, D.E., A.-M.P. and H.A.; investigation, H.H. and H.A.; resources, D.E.; data curation, H.H.; writing-original draft preparation, H.H. and H.A.; writing—review and editing, H.H., D.E., A.-M.P. and H.A.; visualization, H.H., D.E., A.-M.P. and H.A.; supervision, D.E.; project administration, H.H.; funding acquisition, D.E. All authors have read and agreed to the published version of the manuscript.

Funding: The work is funded by Greyhound Racing New South Wales with UTS institution reference of PRO17-3051.

Conflicts of Interest: The authors declare no conflict of interest.

\section{References}

1. Eager, D.; Pendrill, A.M.; Reistad, N. Beyond velocity and acceleration: Jerk, snap and higher derivatives. Eur. J. Phys. 2016, 37, 65-68. [CrossRef]

2. Pendrill, A.M. Rollercoaster loop shapes. Phys. Educ. 2005, 40, 517. [CrossRef]

3. Gierlak, P.; Szybicki, D.; Kurc, K.; Burghardt, A.; Wydrzyński, D.; Sitek, R.; Goczał, M. Design and dynamic testing of a roller coaster running wheel with a passive vibration damping system. J. Vibroeng. 2018, 20, 1129-1143. [CrossRef]

4. Sicat, S.; Woodcock, K.; Ferworn, A. Wearable Technology for Design and Safety Evaluation of Rider Acceleration Exposure on Aerial Adventure Attractions. In Proceedings of the Annual Occupational Ergonomics and Safety Conference, Pittsburgh, PA, USA, 7-8 June 2018.

5. Vaisanen, A. Design of Roller Coasters. Master's Thesis, Aalto University, Espoo, Finland, 2018.

6. Pendrill, A.M.; Eriksson, M.; Eriksson, U.; Svensson, K.; Ouattara, L. Students making sense of motion in a vertical roller coaster loop. Phys. Educ. 2019, 54, 065017. [CrossRef]

7. Pendrill, A.M.; Eager, D. Velocity, acceleration, jerk, snap and vibration: Forces in our bodies during a roller coaster ride. Phys. Educ. 2020, 55, 065012. [CrossRef]

8. Coats, T.W.; Haupt, K.D.; Murphy, H.P.; Ganey, N.C.; Riley, M.R. A Guide for Measuring, Analyzing, and Evaluating Accelerations Recorded During Seakeeping Trials of High-Speed Craft; Report; Naval Surface Warfare Center Carderock Division: Norfolk, VA, USA, 2016.

9. Sosa, L.; Ooms, J. A Comfort Analysis of an $86 \mathrm{~m}$ Yacht Fitted with Fin Stabilizers Vs. Magnus-Effect Rotors; Report; The Society of Naval Architects and Marine Engineers: Alexandria, VA, USA, 2016.

10. Werkman, J. Determining and Predicting the Seakeeping Performance of Ships Based on Jerk in the Ship Motions. Master's Thesis, Delft University of Technology, Delft, The Netherlands, 2019. 
11. Nemes, A.; Mester, G. Energy Efficient Feasible Autonomous Multi-Rotor Unmanned Aerial Vehicles Trajectories. In Proceedings of the 4th International Scientific Conference on Advances in Mechanical, Engineering, Debrecen, Hungary, 13-15 October 2016; pp. 369-376.

12. Bae, I.; Moon, J.; Seo, J. Toward a Comfortable Driving Experience for a Self-Driving Shuttle Bus. Electronics 2019, 8, 943. [CrossRef]

13. ISO-2041 Mechanical Vibration, Shock and Condition Monitoring-Vocabulary; Standard; International Organization for Standardization: Geneva, Switzerland, 2009.

14. ISO/TC 17929 Biomechanical Effects on Amusement Ride Passengers; Standard; International Organization for Standardization: Geneva, Switzerland, 2014.

15. ISO 11026 Heavy Commercial Vehicles and Buses_Test Method for Roll Stability_Closing-Curve Test; Standard; International Organization for Standardization: Geneva, Switzerland, 2010.

16. ISO 15623 Intelligent Transport Systems_Forward Vehicle Collision Warning Systems_Performance Requirements and Test Procedures; Standard; International Organization for Standardization: Geneva, Switzerland, 2013.

17. ISO 18737-1: Measurement of Ride Quality_Part 1: Lifts (Elevators); Standard; International Organization for Standardization: Geneva, Switzerland, 2012.

18. ISO/TS 14649-201: Industrial Automation and Integration-Physical Device Control-Data Model for Computerized Numerical Controllers_-Part 201: Machine Tool Data for Cutting Processes; Standard; International Organization for Standardization: Geneva, Switzerland, 2012.

19. ISO 25745-2: Energy Performance of Lifts, Escalators and Moving Walks-Part 2: Energy Calculation and Classification for Lifts (Elevators); Standard; International Organization for Standardization: Geneva, Switzerland, 2015.

20. Sandin, T. The jerk. Phys. Teach. 1990, 28, 36-40. [CrossRef]

21. Sears, F.W.; Zemansky, M.W.; Young, H.D. University Physics; Addison-Wesley: Boston, MA, USA, 1987.

22. Schot, S.H. Jerk: the time rate of change of acceleration. Am. J. Phys. 1978, 46, 1090-1094. [CrossRef]

23. Lalanne, C. Mechanical Vibration and Shock Analysis, Fatigue Damage; John Wiley \& Sons: Hoboken, NJ, USA, 2010.

24. Smith, J.D. Vibration Measurement and Analysis; Butterworth-Heinemann: Oxford, UK, 2013.

25. Jia, J. Essentials of Applied Dynamic Analysis; Springer: Berlin/Heidelberg, Germany, 2014.

26. Thompson, P.M. Snap crackle and pop. In Proceedings of the AIAA Southern California Aerospace Systems and Technology Conference, Hawthorne, CA, USA, 2011. Available online: http:/ / www.justuslearning. com/wp-content/uploads/2013/12/AIAAOC_SnapCracklePop_docx.pdf (accessed on 21 October 2020).

27. Besset, P.; Béarée, R. FIR filter-based online jerk-constrained trajectory generation. Control Eng. Pract. 2017, 66, 169-180. [CrossRef]

28. Bianco, C.G.L.; Ghilardelli, F. A scaling algorithm for the generation of jerk-limited trajectories in the operational space. Robot. Comput.-Integr. Manuf. 2017, 44, 284-295. [CrossRef]

29. Chen, S.L.; Li, X.; Teo, C.S.; Tan, K.K. Composite jerk feedforward and disturbance observer for robust tracking of flexible systems. Automatica 2017, 80, 253-260. [CrossRef]

30. Chen, D.; Li, S.; Li, W.; Wu, Q. A multi-level simultaneous minimization scheme applied to jerk-bounded redundant robot manipulators. IEEE Trans. Autom. Sci. Eng. Comput. 2019, 17, 463-474. [CrossRef]

31. Chen, D.; Zhang, Y. Minimum jerk norm scheme applied to obstacle avoidance of redundant robot arm with jerk bounded and feedback control. IET Control Theory Appl. 2016, 10, 1896-1903. [CrossRef]

32. Chen, D.; Zhang, Y. Jerk-level synchronous repetitive motion scheme with gradient-type and zeroing-type dynamics algorithms applied to dual-arm redundant robot system control. Int. J. Syst. Sci. 2017, 48, 2713-2727. [CrossRef]

33. Dai, C.; Lefebvre, S.; Yu, K.M.; Geraedts, J.M.; Wang, C.C. Planning Jerk-Optimized Trajectory With Discrete Time Constraints for Redundant Robots. IEEE Trans. Autom. Sci. Eng. 2020, 17, 1711-1724. [CrossRef]

34. Dong, H.; Cong, M.; Liu, D.; Wang, G. An effective technique to find a robot joint trajectory of minimum global jerk and distance. In Proceedings of the 2015 IEEE International Conference on Information and Automation, Lijiang, China, 8-10 August 2015; pp. 1327-1330.

35. Duan, H.; Zhang, R.; Yu, F.; Gao, J.; Chen, Y. Optimal trajectory planning for glass-handing robot based on execution time acceleration and jerk. J. Robot. 2016, 2016, 9329131. [CrossRef]

36. Feifei, L.; Fei, L. Time-jerk optimal planning of industrial robot trajectories. Int. J. Robot. Autom. 2016, 31, 1-7. [CrossRef] 
37. Glorieux, E.; Svensson, B.; Danielsson, F.; Lennartson, B. Simulation-based time and jerk optimisation for robotic press tending. In Proceedings of the 29th European Simulation and Modelling Conference, EUROSIS, Leicester, UK, 7-8 October 2015; pp. 377-384.

38. Huang, J.; Hu, P.; Wu, K.; Zeng, M. Optimal time-jerk trajectory planning for industrial robots. Mech. Mach. Theory 2018, 121, 530-544. [CrossRef]

39. Jiang, L.; Lu, S.; Gu, Y.; Zhao, J. Time-Jerk Optimal Trajectory Planning for a 7-DOF Redundant Robot Using the Sequential Quadratic Programming Method. In International Conference on Intelligent Robotics and Applications; Springer: Berlin/Heidelberg, Germany, 2017; pp. 343-353.

40. Kaserer, D.; Gattringer, H.; Müller, A. Online Robot-Object Synchronization With Geometric Constraints and Limits on Velocity, Acceleration, and Jerk. IEEE Robot. Autom. Lett. 2018, 3, 3169-3176. [CrossRef]

41. Kaserer, D.; Gattringer, H.; Müller, A. Nearly optimal path following with jerk and torque rate limits using dynamic programming. IEEE Trans. Robot. 2018, 35, 521-528. [CrossRef]

42. Lange, F.; Albu-Schäffer, A. Path-accurate online trajectory generation for jerk-limited industrial robots. IEEE Robot. Autom. Lett. 2015, 1, 82-89. [CrossRef]

43. Lange, F.; Suppa, M. Trajectory generation for immediate path-accurate jerk-limited stopping of industrial robots. In Proceedings of the 2015 IEEE International Conference on Robotics and Automation (ICRA), Seattle, WA, USA, 26-30 May 2015; pp. 2021-2026.

44. Lange, F.; Suppa, M. Trajectory Generation for Path-Accurate Jerk-Limited Sensor-Based Path Corrections of Robot Arms. In Proceedings of the IEEE International Conference on Robotics and Automation (ICRA), Seattle, WA, USA, 26-30 May 2015; pp. 4087-4087.

45. Liu, L.; Chen, C.; Zhao, X.; Li, Y. Smooth trajectory planning for a parallel manipulator with joint friction and jerk constraints. Int. J. Control Autom. Syst. 2016, 14, 1022-1036. [CrossRef]

46. Lu, S.; Li, Y. Minimum-Jerk Trajectory Planning of a 3-DOF Translational Parallel Manipulator. In Proceedings of the ASME 2015 International Design Engineering Technical Conferences and Computers and Information in Engineering Conference, Boston, MA, USA, 2-5 August 2015.

47. Lu, S.; Ding, B.; Li, Y. Minimum-jerk trajectory planning pertaining to a translational 3-degree-of-freedom parallel manipulator through piecewise quintic polynomials interpolation. Adv. Mech. Eng. 2020, 12, 1687814020913667. [CrossRef]

48. Lu, S.; Zhao, J.; Jiang, L.; Liu, H. Solving the time-jerk optimal trajectory planning problem of a robot using augmented lagrange constrained particle swarm optimization. Math. Probl. Eng. 2017, 2017. [CrossRef]

49. Palleschi, A.; Garabini, M.; Caporale, D.; Pallottino, L. Time-Optimal Path Tracking for Jerk Controlled Robots. IEEE Robot. Autom. Lett. 2019, 4, 3932-3939. [CrossRef]

50. Park, B.J.; Lee, H.J.; Oh, K.K.; Moon, C.J. Jerk-Limited Time-Optimal Reference Trajectory Generation for Robot Actuators. Int. J. Fuzzy Log. Intell. Syst. 2017, 17, 264-271. [CrossRef]

51. Rezaeifar, H.; Najafi, F. Path planning using via-points and Jerk-minimum method with static obstacles for a 7 DOF manipulator. Modares Mech. Eng. 2015, 15, 153-163.

52. Rojas, R.A.; Garcia, M.A.R.; Wehrle, E.; Vidoni, R. A Variational Approach to Minimum-Jerk Trajectories for Psychological Safety in Collaborative Assembly Stations. IEEE Robot. Autom. Lett. 2019, 4, 823-829. [CrossRef]

53. Rout, A.; Dileep, M.; Mohanta, G.B.; Deepak, B.; Biswal, B. Optimal time-jerk trajectory planning of 6 axis welding robot using TLBO method. Procedia Comput. Sci. 2018, 133, 537-544. [CrossRef]

54. Rout, A.; Mohanta, G.B.; Gunji, B.M.; Deepak, B.; Biswal, B.B. Optimal time-jerk-torque trajectory planning of industrial robot under kinematic and dynamic constraints. In Proceedings of the 2019 9th Annual Information Technology, Electromechanical Engineering and Microelectronics Conference (IEMECON), Jaipur, India, 13-15 March 2015; pp. 36-42.

55. Shi, X.; Fang, H.; Guo, W. Time-Energy-Jerk Optimal Trajectory Planning of Manipulators Based on Quintic NURBS. Mach. Des. Res. 2017, 2017, 45. [CrossRef]

56. Shi, X.L.; Fang, H.G. Time-Energy-Jerk Optimal Planning of Industrial Robot Trajectories. Mach. Des. Manuf. 2018, 66. [CrossRef]

57. Shimada, N.; Yoshioka, T.; Ohishi, K.; Miyazaki, T.; Yokokura, Y. Variable dynamic threshold of jerk signal for contact detection in industrial robots without force sensor. Electr. Eng. Jpn. 2015, 193, 43-54. [CrossRef]

58. Wang, P.; Yang, H.; Xue, K. Jerk-optimal trajectory planning for stewart platform in joint space. In Proceedings of the 2015 IEEE International Conference on Mechatronics and Automation (ICMA), Beijing, China, 2-5 August 2015; pp. 1932-1937. 
59. Yue, S.; Yinya, L.; Guoqing, Q.; Andong, S. Time-jerk Optimal Trajectory Planning for Industrial Robots Based on PSO Algorithm. Comput. Meas. Control 2017, 2017, 45.

60. Zeeshan, M.; Xu, H. Jerk-Bounded Trajectory Planning of Industrial Manipulators. In Proceedings of the 2019 IEEE International Conference on Robotics and Biomimetics (ROBIO), Dali, China, 6-8 December 2019; pp. 1089-1096.

61. Zhang, D.; Wu, F.; Li, R. Time-optimal and minimum-jerk trajectory planning of 3-DOF PM spherical motor. In Proceedings of the 2017 IEEE International Conference on Mechatronics and Automation (ICMA), Takamatsu, Japan, 6-9 August 2017; pp. 1843-1847.

62. Zhang, Y.; Yang, M.; Qiu, B.; Luo, J.; Tan, H. Jerk-level solutions to manipulator inverse kinematics with mathematical equivalence of operations discovered. In Proceedings of the 2016 12th International Conference on Natural Computation, Fuzzy Systems and Knowledge Discovery (ICNC-FSKD), Changsha, China, 13-15 August 2016; pp. 2121-2126.

63. Zhao, R.; Sidobre, D. Trajectory smoothing using jerk bounded shortcuts for service manipulator robots. In Proceedings of the 2015 IEEE/RSJ International Conference on Intelligent Robots and Systems (IROS), Hamburg, Germany, 28 September-2 October 2015; pp. 4929-4934.

64. Zhang, L.; Du, J. Acceleration smoothing algorithm based on jounce limited for corner motion in high-speed machining. Int. J. Adv. Manuf. Technol. 2018, 95, 1487-1504. [CrossRef]

65. Alzaydi, A. Time-optimal, minimum-jerk, and acceleration continuous looping and stitching trajectory generation for 5-axis on-the-fly laser drilling. Mech. Syst. Signal Process. 2019, 121, 532-550. [CrossRef]

66. Besset, P.; Béarée, R.; Gibaru, O. FIR filter-based online jerk-controlled trajectory generation. In Proceedings of the 2016 IEEE International Conference on Industrial Technology (ICIT), Taipei, Taiwan, 14-17 March 2016; pp. 84-89.

67. Bosetti, P.; Ragni, M. Milling Part Program Preprocessing for Jerk-limited, Minimum-time Tool Paths Based on Optimal Control Theory. IEEJ J. Ind. Appl. 2016, 5, 53-60. [CrossRef]

68. Dumanli, A.; Sencer, B. Optimal high-bandwidth control of ball-screw drives with acceleration and jerk feedback. Precis. Eng. 2018, 54, 254-268. [CrossRef]

69. Hashemian, A.; Bo, P.; Bartoň, M. Reparameterization of ruled surfaces: Toward generating smooth jerk-minimized toolpaths for multi-axis flank CNC milling. Comput.-Aided Des. 2020, 127, 102868. [CrossRef]

70. Huang, J.; Zhu, L.M. Feedrate scheduling for interpolation of parametric tool path using the sine series representation of jerk profile. Proc. Inst. Mech. Eng. Part B J. Eng. Manuf. 2017, 231, 2359-2371. [CrossRef]

71. Li, H.; Wu, W.J.; Rastegar, J.; Guo, A. A real-time and look-ahead interpolation algorithm with axial jerk-smooth transition scheme for computer numerical control machining of micro-line segments. Proc. Inst. Mech. Eng. Part B J. Eng. Manuf. 2019, 233, 2007-2019. [CrossRef]

72. Lin, M.T.; Yu, N.T.; Chiu, W.T.; Lee, C.Y.; Lu, Y.M. A master-axis-based feedrate scheduling with jerk constraints for five-axis tool center point trajectory. In Proceedings of the 2015 IEEE International Conference on Automation Science and Engineering (CASE), Gothenburg, Sweden, 24-28 August 2015; pp. 111-116.

73. Mutlu, M.K.; Keysan, O.; Ulutas, B. Limited-Jerk Sinusoidal Trajectory Design for FOC of PMSM with H-Infinity Optimal Controller. In Proceedings of the 2018 IEEE 18th International Power Electronics and Motion Control Conference (PEMC), Budapest, Hungary, 26-30 August 2018; pp. 704-710.

74. Schroedter, R.; Roth, M.; Janschek, K.; Sandner, T. Flatness-based open-loop and closed-loop control for electrostatic quasi-static microscanners using jerk-limited trajectory design. Mechatronics 2018, 56, 318-331. [CrossRef]

75. Weng, W.H.; Kuo, C.F.J. Jerk decision for free-form surface effects in multi-axis synchronization manufacturing. Int. J. Adv. Manuf. Technol. 2019, 105, 799-812. [CrossRef]

76. Zhang, Y.; Ye, P.; Wu, J.; Zhang, H. An optimal curvature-smooth transition algorithm with axis jerk limitations along linear segments. Int. J. Adv. Manuf. Technol. 2018, 95, 875-888. [CrossRef]

77. Zhang, Y.; Ye, P.; Zhang, H.; Zhao, M. A local and analytical curvature-smooth method with jerk-continuous feedrate scheduling along linear toolpath. Int. J. Precis. Eng. Manuf. 2018, 19, 1529-1538. [CrossRef]

78. Zhang, Y.; Zhao, M.; Ye, P.; Zhang, H. A G4 continuous B-spline transition algorithm for CNC machining with jerk-smooth feedrate scheduling along linear segments. Comput.-Aided Des. 2019, 115, 231-243. [CrossRef]

79. Ansoategui, I.; Campa, F.J. Mechatronic Model Based Jerk Optimization in Servodrives with Compliant Load. In European Conference on Mechanism Science; Springer: Berlin/Heidelberg, Germany, 2018; pp. 45-52. 
80. Fang, J.H.; Guo, F.; Chen, Z.; Wei, J.H. Improved sliding-mode control for servo-solenoid valve with novel switching surface under acceleration and jerk constraints. Mechatronics 2017, 43, 66-75. [CrossRef]

81. Liu, J.; Cai, S.; Chen, W.; Chen, I.M. Minimum-jerk trajectory generation and global optimal control for permanent magnet spherical actuator. In Proceedings of the 2017 IEEE International Conference on Robotics and Biomimetics (ROBIO), Macau, China, 5-8 December 2017; pp. 2249-2254.

82. Masoudi, S.; Feyzi, M.R.; Sharifian, M.B.B. Force ripple and jerk minimisation in double sided linear switched reluctance motor used in elevator application. IET Electr. Power Appl. 2016, 10, 508-516. [CrossRef]

83. Wu, F.; Zhai, X.; Zhang, D.; Li, R. Minimum-Jerk Trajectory Planning of 3-DOF PM Spherical Motor. Small Spec. Electr. Mach. 2016, 10, 82-85.

84. Bui, H.T. Toolpath Planning Methodology for Multi-Gantry Fused Filament Fabrication 3D Printing. Master's Thesis, University of Arkansas, Fayetteville, AR, USA, 2019.

85. Chen, S.L.; Ma, J.; Teo, C.S.; Kong, C.J.; Lin, W.; Tay, A.; Al Mamun, A. A constrained linear quadratic optimization approach to jerk decoupling cartridge design for vibration suppression. In Proceedings of the 2015 IEEE International Conference on Advanced Intelligent Mechatronics (AIM), Busan, Korea, 7-11 July 2015; pp. 1472-1477.

86. Hernandez, D.D. Factors affecting dimensional precision of consumer 3D printing. Int. J. Aviat. Aeronaut. Aerosp. 2015, 2, 2. [CrossRef]

87. Kamaldin, N.; Chen, S.L.; Teo, C.S.; Lin, W.; Tan, K.K. A novel adaptive jerk control with application to large workspace tracking on a flexure-linked dual-drive gantry. IEEE Trans. Ind. Electron. Autom. 2018, 66, 5353-5363. [CrossRef]

88. Ma, J.; Chen, S.L.; Teo, C.S.; Kong, C.J.; Tay, A.; Lin, W.; Al Mamun, A. A constrained linear quadratic optimization algorithm toward jerk-decoupling cartridge design. J. Frankl. Inst. 2017, 354, 479-500. [CrossRef]

89. Mab, J.; Chena, S.L.; SingTeoc, C.; Kongc, C.J.; Tayb, A.; Linc, W.; Al Mamunb, A. Constrained linear quadratic optimization for jerk-decoupling cartridge design. Precis. Motion Syst. Model. Control Appl. 2019, 2019, 13.

90. Whyman, S.; Arif, K.M.; Potgieter, J. Design and development of an extrusion system for 3D printing biopolymer pellets. Int. J. Adv. Manuf. Technol. 2018, 96, 3417-3428. [CrossRef]

91. Visser, M. Jerk, snap and the cosmological equation of state. Class. Quantum Gravity 2004, 21, 2603. [CrossRef]

92. Hur-Diaz, S.; Wirzburger, J.; Smith, D. Three Axis Control of the Hubble Space Telescope Using Two Reaction Wheels and Magnetic Torquer Bars for Science Observations; Report; The National Aeronautics and Space Administration: Washington, DC, USA, 2008.

93. Ramon, R.G. Model for Touchdown Dynamics of a Lander on the Solar Power Sail Mission. Master's Thesis, Luleå University of Technology, Kingston, Jamaica, 2016.

94. STD, N. 3001. NASA Space Flight Human-System Standard, Volume 2: Human Factors, Habitability, and Environmental Health; The National Aeronautics and Space Administration: Washington, DC, USA, 2011.

95. Abuasaker, S. Anti-Jerk Controller with Optimisation-Based Self-Tuning. Ph.D. Thesis, University of Surrey, Guildford, UK, 2016.

96. Anderson, D.; Desaix, M.; Nyqvist, R. The least uncomfortable journey from A to B. Am. J. Phys. 2016, 84, 690-695. [CrossRef]

97. Antonelli, R.; Klotz, A.R. A smooth trip to Alpha Centauri: The least uncomfortable journey from A to B. Am. J. Phys. 2017, 85, 469-472. [CrossRef]

98. Batra, M. Dynamics and Model-Predictive Anti-Jerk Control of Connected Electric Vehicles. Ph.D. Thesis, University of Waterloo, Waterloo, ON, Canada, 2018.

99. Batra, M.; Maitland, A.; McPhee, J.; Azad, N.L. Non-linear model predictive anti-jerk cruise control for electric vehicles with slip-based constraints. In Proceedings of the 2018 Annual American Control Conference (ACC), Milwaukee, WI, USA, 27-29 June 2018; pp. 3915-3920.

100. Batra, M.; McPhee, J.; Azad, N.L. Anti-jerk model predictive cruise control for connected electric vehicles with changing road conditions. In Proceedings of the 2017 11th Asian Control Conference (ASCC), Gold Coast, QLD, Australia, 17-20 December 2017; pp. 49-54.

101. Batra, M.; McPhee, J.; Azad, N.L. Anti-jerk dynamic modeling and parameter identification of an electric vehicle based on road tests. J. Comput. Nonlinear Dyn. 2018, 13, 101005. [CrossRef]

102. Darokar, K.K. Automotive Driveline Backlash State and Size Estimator Design for Anti-Jerk Control. Master's Thesis, Michigan Technology University, Houghton, MI, USA, 2019. 
103. Deshmukh, A.; Mulani, B.; Jadhav, N.; Parihar, A.S. Study of frequency characteristics of vehicle motions for the derivation of inherent jerk. Int. J. Passeng. Cars-Mech. Syst. 2016, 9, 419-423. [CrossRef]

104. Förstberg, J. Ride Comfort and Motion Sickness in Tilting Trains. Ph.D. Thesis, Institutionen för Farkostteknik, Lund, Sweden, 2000.

105. Gangadharan, K.; Sujatha, C.; Ramamurti, V. Experimental and analytical ride comfort evaluation of a railway coach. In Proceedings of the SEM ORG IMAC XXII, 2004, Conf; pp. 1-15. Available online: https:/ / www.semanticscholar.org/paper/Experimental-and-Analytical-Ride-Comfort-EvaluationGangadharan/671e4c731e0ec2b4da82b0482373d61531730a9d?p2df (accessed on 21 October 2020).

106. George, T.K.; Gadhia, H.M.; Sukumar, R.; Cabibihan, J.J. Sensing discomfort of standing passengers in public rail transportation systems using a smart phone. In Proceedings of the 2013 10th IEEE International Conference on Control and Automation (ICCA), Hangzhou, China, 12-14 June 2013; pp. 1509-1513.

107. Grant, P.R.; Haycock, B. Effect of jerk and acceleration on the perception of motion strength. J. Aircr. 2008, 45, 1190-1197. [CrossRef]

108. Hoberock, L.L. A Survey of Longitudinal Acceleration Comfort Studies in Ground Transportation Vehicles; Report; Council for Advanced Transportation Studies: Austin, TX, USA, 1976.

109. Huang, W.; Wong, P.K.; Zhao, J.; Ma, X. Output-feedback model-reference adaptive calibration for map-based anti-jerk control of electromechanical automotive clutches. Int. J. Adapt. Control Signal Process. 2018, 32, 265-285. [CrossRef]

110. Ikuhisa, K.; Lu, X.; Ota, T.; Hamada, H.; Kida, N.; Goto, A. Evaluation of Comfortable Using Jerk Method During Transfer Caring. In Congress of the International Ergonomics Association; Springer: Berlin/Heidelberg, Germany, 2018; pp. 178-188.

111. Ismail, K.; Susanto, B.; Sholahuddin, U.; Sabar, M. Design of Motor Control Electric Push-Scooter using Accelerometer as Jerk Sensor. In Proceedings of the 2019 International Conference on Sustainable Energy Engineering and Application (ICSEEA), Tangerang, Indonesia, 23-24 October 2019; pp. 69-73.

112. Khorram, B.; Af Wåhlberg, A.; Tavakoli Kashani, A. Longitudinal jerk and celeration as measures of safety in bus rapid transit drivers in Tehran. Theor. Issues Ergon. Sci. 2020, 21, 577-594. [CrossRef]

113. Kilinc, A.S.; Baybura, T. Determination of minimum horizontal curve radius used in the design of transportation structures, depending on the limit value of comfort criterion lateral jerk. In TS06G-Engineering Surveying, Machine Control and Guidance; Rome, Italy, 2012. Available online: https://www.fig.net/ resources/proceedings/fig_proceedings/fig2012/papers/ts06g/TS06G_kilinc_baybura_5563.pdf (accessed on 21 October 2020).

114. Kruger, T.J. Graph-Based Speed Planning for Autonomous Driving. Master's Thesis, Free University of Berlin, Berlin, Germany, 2019.

115. Kushiro, I.; Suzuki, K. Mathematical model of skilled driver's steering pattern based on minimum jerk model. Trans. Soc. Automot. Eng. Jpn. 2016, 47, 1103-1110.

116. Lemos, N.A. On the least uncomfortable journey from A to B. Eur. J. Phys. 2019, 40, 055802. [CrossRef]

117. Liu, Y.; Zuo, L. Mixed skyhook and power-driven-damper: A new low-jerk semi-active suspension control based on power flow analysis. J. Dyn. Syst. Meas. Control 2016, 138, 081009. [CrossRef]

118. Martin, D.; Litwhiler, D.H. An Investigation of acceleration and jerk profiles of public transportation vehicles. In Proceedings of the ASEE Annual Conference and Exposition, Pittsburgh, PA, USA, 22-25 June 2008.

119. Reddy, G.V.P. Control Oriented Modeling of an Automotive Drivetrain for Anti-Jerk Control. Master's Thesis, Michigan Technological University, Houghton, MI, USA, 2018.

120. Scamarcio, A.; Metzler, M.; Gruber, P.; De Pinto, S.; Sorniotti, A. Comparison of anti-jerk controllers for electric vehicles with on-board motors. IEEE Trans. Veh. Technol. 2020. [CrossRef]

121. Sharma, S.K.; Chaturvedi, S. Jerk analysis in rail vehicle dynamics. Perspect. Sci. 2016, 8, 648-650. [CrossRef]

122. Shigehiro, R.; Aguilar, G.D.; Kuroda, T. Evaluation method of seakeeping performance for training ships from the viewpoint of passenger comfort. Fish. Sci. 2002, 68, 1827-1830. [CrossRef]

123. Svensson, L.; Eriksson, J. Tuning for Ride Quality in Autonomous Vehicle: Application to Linear Quadratic Path Planning Algorithm. Master's Thesis, Uppsala University, Uppsala, Sweden, 2015.

124. Tawadros, P.; Awadallah, M.; Walker, P.; Zhang, N. Using a low-cost bluetooth torque sensor for vehicle jerk and transient torque measurement. Proc. Inst. Mech. Eng. Part D J. Automob. Eng. 2020, 234, $423-437$. [CrossRef] 
125. Tawadros, P.S. Powertrain Electrification for Jerk Reduction and Continuous Torque Delivery. Ph.D. Thesis, Universoty of Technology Sydney, Sydney, Australia, 2019.

126. Tomi, T. A study on ship vibration and oscillation limits from the viewpoint of unpleasant feelings of passengers (1st report-The susceptibility of human beings to motions). Jpn. Soc. Nav. Archit. Ocean Eng. 1961, 104, 18-30.

127. Vallee, P.; Robert, T. A numerical model to assess the risk of fall in public transportation-application to the influence of the Jerk in emergency braking. In Proceedings of the IRCOBI Conference, Lyon, France, 9-11 September 2015.

128. Van Santen, G.W. Introduction to a Study of Mechanical Vibration: UDC No. 534.1: 621-752; Philips Technical Library: London, UK, 1953. Available online: https://science.sciencemag.org/content/120/3109/179.2 (accessed on 21 October 2020).

129. Veerapaneni, N.V.M. Real-Time Minimum Jerk Optimal Trajectory Synthesis and Tracking for Ground Vehicle Applications. Master's Thesis, University of Texas, Austin, TX, USA, 2018.

130. Yamaguchi, A.; Ohishi, K.; Yokokura, Y.; Miyazaki, T.; Sasazaki, K. Backlash-based Shock Isolation Control for Jerk Reduction in Clutch Engagement. IEEJ J. Ind. Appl. 2019, 8, 160-169. [CrossRef]

131. Zeng, X.; Cui, H.; Song, D.; Yang, N.; Liu, T.; Chen, H.; Wang, Y.; Lei, Y. Jerk analysis of a power-split hybrid electric vehicle based on a data-driven vehicle dynamics model. Energies 2018, 11, 1537. [CrossRef]

132. Muszynska, A.; Bently, D. Frequency-swept rotating input perturbation techniques and identification of the fluid force models in rotor/bearing/seal systems and fluid handling machines. J. Sound Vib. 1990, 143, 103-124. [CrossRef]

133. Muszynska, A.; Bently, D.E. Comments on Frequency Swept Rotating Input Perturbation Techniques and Identification of the Fluid Force Models in Rotor/bearing/seal Systems and Fluid Handling Machines; Report; 1991. Available online: https://ntrs.nasa.gov/citations/19920005152 (accessed on 21 October 2020).

134. Inaudi, J.A.; Kelly, J.M. Hybrid isolation systems for equipment protection. Earthq. Eng. Struct. Dyn. 1993, 22, 297-313. [CrossRef]

135. Funakoshi, D.; Okada, S.; Watanabe, T.; Seto, K. Levitation and Vibration Supression of an Elastic Rotor by Using Active Magnetic Bearings. In Proceedings of the ASME 2012 5th Annual Dynamic Systems and Control Conference Joint with the JSME 2012 11th Motion and Vibration Conference, Fort Lauderdale, FL, USA, 17-19 October 2012; pp. 61-65.

136. Eager, D. Accelerometers used in the measurement of jerk, snap, and crackle. In Proceedings of the Australian Acoustical Society 2018 Annual Conference, Adelaide, Australia, 6-9 November 2018.

137. Kwon, B.M.; Moon, J.H.; Choi, H.D. Performance analysis of the GPS receiver under high acceleration and jerk environments. In Proceedings of the Korean Institute of Navigation and Port Research Conference, 2006; Volume 2, pp. 279-283. Available online: https:/ / www.koreascience.or.kr/article/CFKO200636035497527. page (accessed on 21 October 2020)

138. Kwon, B.M.; Moon, J.H.; Choi, H.D.; Cho, G.R. Comparative Performance Analyses of GPS Receivers under High-Dynamic Conditions. In Proceedings of the 17th World Congress The International Federation of Automatic Control, Seoul, Korea, 6-11 July 2008; Volume 41, pp. 4725-4730.

139. Fazio, P.; Granieri, G.; Casetta, I.; Cesnik, E.; Mazzacane, S.; Caliandro, P.; Pedrielli, F.; Granieri, E. Gait measures with a triaxial accelerometer among patients with neurological impairment. Neurol. Sci. 2013, 34, 435-440. [CrossRef]

140. Lapinski, M.T. A Platform for High-Speed Bio-Mechanical Analysis Using Wearable Wireless Sensors. Ph.D. Thesis, Massachusetts Institute of Technology, Cambridge, MA, USA, 2013.

141. Aguirre, A. Evaluation of a Technological Device for Upper-Limb Motor Assessment. Ph.D. Thesis, San Francisco State University, San Francisco, CA, USA, 2016.

142. Zhang, L.; Diraneyya, M.M.; Ryu, J.; Haas, C.T. Jerk as an indicator of physical exertion and fatigue. Autom. Constr. 2019, 104, 120-128. [CrossRef]

143. Washington, J.K.; Oliver, G.D. Relationship of pelvis and torso angular jerk to hand velocity in female softball hitting. J. Sport. Sci. 2020, 38, 46-52. [CrossRef]

144. de Lucena, D.S.; Stoller, O.; Rowe, J.B.; Chan, V.; Reinkensmeyer, D.J. Wearable sensing for rehabilitation after stroke: Bimanual jerk asymmetry encodes unique information about the variability of upper extremity recovery. In Proceedings of the 2017 International Conference on Rehabilitation Robotics (ICORR), London, UK, 17-20 July 2017; pp. 1603-1608. 
145. Zhang, L.; Diraneyya, M.M.; Ryu, J.; Haas, C.T.; Abdel-Rahman, E. Assessment of Jerk as a Method of Physical Fatigue Detection. In Proceedings of the ASME 2018 International Design Engineering Technical Conferences and Computers and Information in Engineering Conference, Quebec City, QC, Canada, 26-29 August 2018.

146. Zhang, L.; Diraneyya, M.; Ryu, J.; Haas, C.; Abdel-Rahman, E. Automated Monitoring of Physical Fatigue Using Jerk. In Proceedings of the International Symposium on Automation and Robotics in Construction, Banff, AB, Canada, 21-24 May 2019; Volume 36, pp. 989-997.

147. Zhang, L. Jerk as a Method of Identifying Physical Fatigue and Skill Level in Construction Work. Master's Thesis, University of Waterloo, Waterloo, ON, Canada, 2019.

148. Masuda, A.; Sone, A.; Matsuura, T. Development of Jerk Dot Sensor and Its Application to Condition Monitoring. In Proceedings of the Symposium on Evaluation and Diagnosis; pp. 118-121. Available online: https://www.jstage.jst.go.jp/article/jsmesed/2002.1/0/2002.1_118/_article/-char/ja/ (accessed on 21 October 2020).

149. Orsagh, R.; Brown, D. Sensor for Measuring Jerk and a Method for Use Thereof. U.S. Patent Application 11/191, 2 February 2006.

150. Xueshan, Y.; Xiaozhai, Q.; Lee, G.C.; Tong, M.; Jinming, C. Jerk and jerk sensor. In Proceedings of the 14th World Conference on Earthquake Engineering, Beijing, China, 12-17 October 2008.

151. Manabe, T.; Wakui, S. Production and Application of Horizontal Jerk Sensor. In Proceedings of the 2018 International Conference on Advanced Mechatronic Systems (ICAMechS), Zhengzhou, China, 30 August-2 September 2018; pp. 298-303.

152. Thompson, M. The application of motion capture to embodied music cognition research. Jyväskylä Stud. Humanit. 2012. 176, 146493785.

153. Jongejan, B.; Paggio, P.; Navarretta, C. Classifying head movements in video-recorded conversations based on movement velocity, acceleration and jerk. In Proceedings of the 4th European and 7th Nordic Symposium on Multimodal Communication (MMSYM 2016), Copenhagen, Denmark, 29-30 September 2016; pp. 10-17.

154. Sharker, S.I.; Holekamp, S.; Mansoor, M.M.; Fish, F.E.; Truscott, T.T. Water entry impact dynamics of diving birds. Bioinspiration Biomimetics 2019, 14, 056013. [CrossRef]

155. Hossain, M.; Hayati, H.; Eager, D. A Comparison of the Track Shape of Wentworth Park and Proposed Murray Bridge; Report; University of Technology Sydney: Sydney, Australia, 2016.

156. Hayati, H.; Eager, D.; Jusufi, A.; Brown, T. A Study of Rapid Tetrapod Running and Turning Dynamics Utilizing Inertial Measurement Units in Greyhound Sprinting. In Proceedings of the ASME 2017 International Design Engineering Technical Conferences and Computers and Information in Engineering Conference, Cleveland, OH, USA, 6-9 August 2017.

157. Hayati, H.; Eager, D.; Stephenson, R.; Brown, T.; Arnott, E. The impact of track related parameters on catastrophic injury rate of racing greyhounds. In Proceedings of the 9th Australasian Congress on Applied Mechanics, Sydney, Australia, 27-29 November 2017; p. 311.

158. Hayati, H.; Walker, P.; Mahdavi, F.; Stephenson, R.; Brown, T.; Eager, D. A comparative study of rapid quadrupedal sprinting and turning dynamics on different terrains and conditions: Racing greyhounds galloping dynamics. In Proceedings of the ASME 2018 International Mechanical Engineering Congress and Exposition, Pittsburgh, PA, USA, 11-14 November 2018.

159. Mahdavi, F.; Hossain, M.I.; Hayati, H.; Eager, D.; Kennedy, P. Track Shape, Resulting Dynamics and Injury Rates of Greyhounds. In Proceedings of the ASME 2018 International Mechanical Engineering Congress and Exposition, Pittsburgh, PA, USA, 11-14 November 2018; p. V013T05A018.

160. Hossain, I.; Eager, D.; Walker, P. Greyhound racing ideal trajectory path generation for straight to bend based on jerk rate minimization. Sci. Rep. 2020, 10, 7088. [CrossRef]

161. Malushte, S.R. Prediction of Seismic Design Response Spectra Using Ground Characteristics. Ph.D. Thesis, Virginia Tech, Blacksburg, VA, USA, 1987.

162. Bertero, R.D.; Bertero, V.V. Performance-based seismic engineering: The need for a reliable conceptual comprehensive approach. Earthq. Eng. Struct. Dyn. 2002, 31, 627-652. [CrossRef]

163. Geoffrey Chase, J.; Barroso, L.R.; Hunt, S. Quadratic jerk regulation and the seismic control of civil structures. Earthq. Eng. Struct. Dyn. 2003, 32, 2047-2062. [CrossRef]

164. Tong, M.; Wang, G.Q.; Lee, G.C. Time derivative of earthquake acceleration. Earthq. Eng. Eng. Vib. 2005, 4, 1-16. [CrossRef] 
165. He, H.; Li, R.; Chen, K. Characteristics of jerk response spectra for elastic and inelastic systems. Shock Vib. 2015, 2015. Available online: https:/ /www.hindawi.com/journals/sv/2015/782748/ (accessed on 21 October 2020). [CrossRef]

166. Chakraborty, S.; Ray-Chaudhuri, S. Energy Transfer to High-Frequency Modes of a Building due to Sudden Change in Stiffness at Its Base. J. Eng. Mech. 2017, 143, 04017050. [CrossRef]

167. Taushanov, A. Jerk Response Spectrum; Report; 2018. Available online: https://www.researchgate. net/profile/Alexander_Taushanov/publication/323150255_Jerk_Response_Spectrum/links/ 5a82e5040f7e9bda86a00d81/Jerk-Response-Spectrum.pdf (accessed on 21 October 2020).

168. Papandreou, I.; Papagiannopoulos, G. On the jerk spectra of some inelastic systems subjected to seismic motions. Soil Dyn. Earthq. Eng. 2019, 126, 105807. [CrossRef]

169. Yaseen, A.A.; Ahmed, M.S.; Al-Kamaki, Y.S.S. Jerk Performance as Seismic Intensity Measure. In Proceedings of the 3rd International Conference on Recent Innovations in Engineering, Duhok, Iraq, 9-10 September 2020.

170. Sofronie, R. On the Seismic Jerk. J. Geol. Resour. Eng. Comput. 2017, 4, 147-152. [CrossRef]

171. Savage, J. The Science of Running Shoes. Technical Report. Available online: http://fellrnr.com/wiki/The_ Science_of_Running_Shoes (accessed on 20 October 2020).

172. Hayati, H.; Eager, D.; Walker, P. An impact attenuation surfacing test to analyse the dynamic behaviour of greyhound racetrack sand surface. In Proceedings of the World Engineers Convention, Melbourne, Australia, 20-22 November 2019; p. 391.

173. Sone, A.; Masuda, A.; Matsuura, T.; Yamamura, T.; Yamada, M.; Yamamoto, S. Detection of structural damages by jerk-dot sensors. Trans. Nippon Kikai Gakkai Ronbunshu C Hen 2004, 16, 1318-1323.

174. Zhang, Z.; Verma, A.; Kusiak, A. Fault analysis and condition monitoring of the wind turbine gearbox. IEEE Trans. Energy Convers. 2012, 27, 526-535. [CrossRef]

175. Iyama, J.; Wakui, M. Threshold value and applicable range of nonlinear behavior detection method using second derivative of acceleration. Jpn. Archit. Rev. 2019, 2, 153-165. [CrossRef]

176. Sumathy, M.; Kilicman, A.; Manuel, M.M.S.; Mary, J. Qualitative study of Riccati difference equation on maneuvering target tracking and fault diagnosis of wind turbine gearbox. Cogent Eng. 2019, 6, 1621423. [CrossRef]

177. Ostermeyer, G.P.; Schiefer, F. On Pain Detection in Multibody Systems. In Applied Mechanics and Materials; Trans Tech Publications: Stafa-Zurich, Switzerland, 2008; Volume 9, pp. 115-126. Available online: https: / / www.scientific.net/AMM.9.115 (accessed on 21 October 2020)

178. Fiori, S.; Sabino, N.; Bonci, A. In-Lab Drone's Attitude Maneuvering Fluency Evaluation by a Gyroscopic Lurch Index. In Proceedings of the 10th International Conference on Circuits, Systems, Signals and Telecommunications, Barcelona, Spain, 13-15 February 2016 pp. 37-46.

179. Guye, K. Development of an Indoor Multirotor Testbed for Experimentation on Autonomous Guidance Strategies. Master's Thesis, South Dakota State University, Brookings, SD, USA, 2018.

180. Lai, S.P.; Lan, M.1.; Li, Y.x.; Chen, B.M. Safe navigation of quadrotors with jerk limited trajectory. Front. Inf. Technol. Electron. Eng. 2019, 20, 107-119. [CrossRef]

181. Luukkonen, T. Modelling and control of quadcopter. Indep. Res. Proj. Appl. Math. 2011, 22. Available online: https:/ / sal.aalto.fi/publications / pdf-files/eluu11_public.pdf (accessed on 21 October 2020).

182. Phang, S.K.; Lai, S.; Wang, F.; Lan, M.; Chen, B.M. Systems design and implementation with jerk-optimized trajectory generation for UAV calligraphy. Mechatronics 2015, 30, 65-75. [CrossRef]

183. Rakgowa, T.; Wong, E.K.; Sim, K.S.; Nia, M. Minimal jerk trajectory for quadrotor VTOL procedure. In Proceedings of the 2015 IEEE International Symposium on Robotics and Intelligent Sensors (IRIS), Langkawi, Malaysia, 18-20 October 2015; pp. 284-287.

184. Rousseau, G.; Maniu, C.S.; Tebbani, S.; Babel, M.; Martin, N. Quadcopter-performed cinematographic flight plans using minimum jerk trajectories and predictive camera control. In Proceedings of the 2018 European Control Conference (ECC), Limassol, Cyprus, 12-15 June 2018; pp. 2897-2903.

185. Silva, J.P.; De Wagter, C.; de Croon, G. Quadrotor Thrust Vectoring Control with Time and Jerk Optimal Trajectory Planning in Constant Wind Fields. Unmanned Syst. 2018, 6, 15-37. [CrossRef]

186. Tal, E.; Karaman, S. Accurate tracking of aggressive quadrotor trajectories using incremental nonlinear dynamic inversion and differential flatness. In Proceedings of the 2018 IEEE Conference on Decision and Control (CDC), Miami Beach, FL, USA, 17-19 December 2018; pp. 4282-4288. 
187. Perri, S.; Bianco, C.G.L.; Locatelli, M. Jerk bounded velocity planner for the online management of autonomous vehicles. In Proceedings of the 2015 IEEE International Conference on Automation Science and Engineering (CASE), Gothenburg, Sweden, 24-28 August 2015; pp. 618-625.

188. Raineri, M.; Bianco, C.G.L. Jerk limited planner for real-time applications requiring variable velocity bounds. In Proceedings of the 2019 IEEE 15th International Conference on Automation Science and Engineering (CASE), Vancouver, BC, Canada, 22-26 August 2019; pp. 1611-1617.

189. Bisoffi, A.; Biral, F.; Da Lio, M.; Zaccarian, L. Longitudinal jerk estimation for identification of driver intention. In Proceedings of the 2015 IEEE 18th International Conference on Intelligent Transportation Systems, Las Palmas, Spain, 15-18 September 2015; pp. 1855-1861.

190. Bisoffi, A.; Biral, F.; Da Lio, M.; Zaccarian, L. Longitudinal jerk estimation of driver intentions for advanced driver assistance systems. IEEE/ASME Trans. Mechatron. 2017, 22, 1531-1541. [CrossRef]

191. Feng, F.; Bao, S.; Sayer, J.R.; Flannagan, C.; Manser, M.; Wunderlich, R. Can vehicle longitudinal jerk be used to identify aggressive drivers? An examination using naturalistic driving data. Accid. Anal. Prev. 2017, 104, 125-136. [CrossRef]

192. Hasan, N. Relationship between Twist, Jerk, and Speed: Twist-Tolerance Values and Measuring Chords. J. Transp. Eng. Part A Syst. 2020, 146, 04020005. [CrossRef]

193. Itkonen, T.H.; Pekkanen, J.; Lappi, O.; Kosonen, I.; Luttinen, T.; Summala, H. Trade-off between jerk and time headway as an indicator of driving style. PLOS ONE 2017, 12, e0185856. [CrossRef]

194. Mousavi, S.M. Identifying High Crash Risk Roadways through Jerk-Cluster Analysis. Master's Thesis, Louisiana State University, Baton Rouge, LA, USA, 2015.

195. Weidner, W.; Transchel, F.W.; Weidner, R. Telematic driving profile classification in car insurance pricing. Ann. Actuar. Sci. 2017, 11, 213-236. [CrossRef]

196. Szabó, I. Geschichte der Mechanischen Prinzipien und Ihrer Wichtigsten Prinzipien; Birkhäuser: Basel, Switzerland, 1977.

197. Dugas, R. Histoire de la Mechanique; Éditions de Griffon: Neuchâtel, Switzerland, 1955.

198. Dugas, R. History of Mechanics, translation by John Maddox of Histoire de la Mechanique; Dover: London, UK, 1988.

199. Wikipedia Contributors. Pierre Varignon-Wikipedia, The Free Encyclopedia. 2018. Available online: https:/ / en.wikipedia.org/wiki/Pierre_Varignon (accessed on 28 May 2020).

200. Melchior, P. Zeitschfrift Ver. Deutsche Ing. 1928, 72, 1842.

201. Schlobach. Gluckauf. Berg- und Huttenmännischen Zeitschrift 1928, 73, 16.

202. Whinnery, T.; Forster, E.M. The+ Gz-induced loss of consciousness curve. Extrem. Physiol. Med. $2013,2,19$. [CrossRef] [PubMed]

203. McKenney, W.R. Human Tolerance to Abrupt Accelerations: A Summary of the Literature; Report; Dynamic Science Inc. Avser Facility: Phoenix, AZ, USA, 1970.

204. Coats, T.W.; Riley, M.R. A Comparison of Shock Isolated Seat and Rigid Seat Acceleration Responses to Wave Impacts in a High-Speed Craft; Report; Naval Surface Warfare Center: Carderock, VA, USA, 2018.

205. Riley, M.R.; Haupt, K.D.; Ganey, H.C.; Coats, T.W. Laboratory Test Requirements for Marine Shock Isolation Seats; Report; Naval Surface Warfare Center Carderock Division: Norfolk, VA, USA, 2018.

206. AASHTO-2001. American Association of State Highway and Transportation Officials; Washington, DC, USA, 2001. Available online: https:/ / www.transportation.org/ (accessed on 21 October 2020).

207. Wasserstein, R.L.; Lazar, N.A. The ASA statement on p-values: Context, process, and purpose. Am. Stat. 2016, 70, 129-133. [CrossRef]

Publisher's Note: MDPI stays neutral with regard to jurisdictional claims in published maps and institutional affiliations.

(C) 2020 by the authors. Licensee MDPI, Basel, Switzerland. This article is an open access article distributed under the terms and conditions of the Creative Commons Attribution (CC BY) license (http:/ / creativecommons.org/licenses/by/4.0/). 